\title{
Is the Affordable Care Act Affecting Retirement Yet?
}

Helen Levy, Thomas Buchmueller, and Sayeh Nikpay

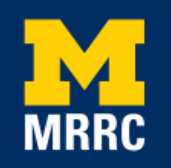

Project \#: R-UM18-04 


\title{
Is the Affordable Care Act Affecting Retirement Yet?
}

\author{
Helen Levy \\ University of Michigan \\ Thomas Buchmueller \\ University of Michigan \\ Sayeh Nikpay \\ Vanderbilt University Medical Center \\ September 2018 \\ Michigan Retirement Research Center \\ University of Michigan \\ P.O. Box 1248 \\ Ann Arbor, MI 48104 \\ www.mrrc.isr.umich.edu \\ (734) 615-0422
}

\section{Acknowledgements}

The research reported herein was performed pursuant to a grant from the U.S. Social Security Administration (SSA) funded as part of the Retirement Research Consortium through the University of Michigan Retirement Research Center Award RRC08098401-10. The opinions and conclusions expressed are solely those of the author(s) and do not represent the opinions or policy of SSA or any agency of the federal government. Neither the United States government nor any agency thereof, nor any of their employees, makes any warranty, express or implied, or assumes any legal liability or responsibility for the accuracy, completeness, or usefulness of the contents of this report. Reference herein to any specific commercial product, process or service by trade name, trademark, manufacturer, or otherwise does not necessarily constitute or imply endorsement, recommendation or favoring by the United States government or any agency thereof.

\section{Regents of the University of Michigan}

Michael J. Behm, Grand Blanc; Mark J. Bernstein, Ann Arbor; Shauna Ryder Diggs, Grosse Pointe; Denise Ilitch, Bingham Farms; Andrea Fischer Newman, Ann Arbor; Andrew C. Richner, Grosse Pointe Park; Ron Weiser, Ann Arbor; Katherine E. White, Ann Arbor; Mark S. Schlissel, ex officio 


\title{
Is the Affordable Care Act Affecting Retirement Yet?
}

\begin{abstract}
We analyze whether the Affordable Care Act (ACA) has affected labor supply of older Americans using data that span more than four years after the policy's implementation in 2014. We find no changes in labor supply of older Americans either in response to subsidized marketplace coverage, which became available nationally in 2014 , or in response to the expansion of Medicaid eligibility in some states but not others. We analyze multiple dimensions of labor supply - labor force participation; employment; full-time work conditional on employment - as well as several measures of retirement including self-reported retirement and the receipt of retirement income. We fail to find labor supply effects even for subgroups with less than a high school education or those with fair or poor health, who might have been expected to have a greater labor supply response. The lack of a labor supply response stands in contrast to the large gains in coverage observed in 2014. These results suggest that for Americans approaching retirement the Affordable Care Act achieved its primary goal of increasing coverage without the unintended consequence of reducing labor supply.
\end{abstract}

\section{Citation}

Levy, Helen, Thomas Buchmueller, and Sayeh Nikpay. 2018. "Is the Affordable Care Act Affecting Retirement Yet?" University of Michigan Retirement Research Center (MRRC) Working Paper, WP 2018-393. Ann Arbor, MI.

https://mrdrc.isr.umich.edu/publications/papers/pdf/wp393.pdf 


\section{Introduction}

The Affordable Care Act, which created subsidized alternatives to employer-sponsored health insurance coverage beginning in 2014, was widely expected to reduce labor supply (U.S. Congressional Budget Office 2014; Harris and Mok 2015; Mulligan 2015). Older workers may have been particularly likely to work less in response to new health insurance options, both because they are at an age when attachment to the labor force begins to weaken and because the ACA prohibition on charging premiums based on health status may have disproportionately benefited older individuals. Nonetheless, studies to date have failed to find any reductions in labor supply in response to the ACA while also documenting large gains in insurance coverage, both in the full population of working-age adults (Leung and Mas forthcoming; Kaestner et al. 2017) and specifically for individuals nearing retirement age (Gustman, Steinmeier, and Tabatabai 2018; Levy, Buchmueller, and Nikpay 2016a). This failure to find an effect of the ACA on retirement is very surprising in light of a well-established literature suggesting that health insurance has historically been an important determinant of retirement. However, retirement behavior may take time to respond to new policies, and these studies may simply have been done too soon to find anything.

In this paper, we revisit the question of whether the ACA has affected labor supply of older Americans, using data that span more than four years after the policy's implementation. We find no changes in labor supply of older Americans in response to the provisions of the ACA, either in response to subsidized marketplace coverage, which became available nationally in 2014, or in response to the expansion of Medicaid eligibility in some states but not others. We look at multiple dimensions of labor supply - labor force participation; employment; full-time work conditional on employment - as well as several measures of retirement including self-reported 
retirement and the receipt of retirement income. We look at both stock and flow measures of these outcomes; that is, for example, we look both at the probability that a given individual is retired at a point in time and at the probability of transitions into or out of retirement. None of these outcomes shows a differential response in expansion versus nonexpansion states. The lack of a labor supply response stands in contrast to the large gains in coverage observed in 2014 . We fail to find labor supply effects even for population subgroups most likely to have benefitted from the new coverage options that became available in 2014: individuals in fair or poor health and those with low levels of education. These results suggest that for Americans approaching retirement the Affordable Care Act achieved its primary goal of increasing coverage without the unintended consequence of reducing labor supply.

\section{Background on the Affordable Care Act}

Beginning in 2014, the Affordable Care Act introduced new, subsidized health insurance options. In every state, the ACA created a health insurance "marketplace" where individuals could purchase nongroup coverage in a regulated market at a community-rated premium. Individuals with incomes between 100 and 400 percent of the federal poverty level (FPL) with no access to affordable coverage from an employer-sponsored plan qualify for advance premium tax credits that limit the amount they can be required to pay for a marketplace plan. These changes to the private nongroup market mean that for a typical individual, retiring from a job with employer-sponsored insurance no longer means giving up affordable coverage.

In addition, in some states, expansion of eligibility for the Medicaid program provides an additional coverage option for very low-income individuals. As of January 1, 2014, 25 states had expanded Medicaid eligibility under the terms of the ACA to all nonelderly adults with family 
income below 138 percent of FPL; an additional seven states expanded between January 2014 and July 2018; and 19 have not yet expanded, as of July 2018.

Collectively, these reforms mean that beginning in 2014, older individuals faced a much lower effective price for health insurance coverage options that did not depend on employment than they had before 2014. In addition, the means-tested health insurance subsidies in the ACA, like any means-tested subsidies, reduce the incentive to supply labor (Mulligan 2014). Both of these effects should, in theory, lead older workers to work less. Thus, we might expect to see a reduction in labor supply among older workers in all states as a result of the availability of marketplace coverage and premium tax credits, with an even larger reduction in states that also expanded their Medicaid programs.

\section{Background on health insurance and retirement}

A large literature analyzes the effect of health insurance on the retirement decision (Blau \& Gilleskie, 2001, 2006, 2008; Fitzpatrick, 2014; French \& Jones, 2011; Gruber \& Madrian, 1995, 1996; Gustman \& Steinmeier, 1994; Johnson, Davidoff, \& Perese, 2003; Karoly \& Rogowski, 1994; Leiserson, 2013; Lumsdaine, Stock, \& Wise, 1996; Madrian \& Beaulieu, 1998; Madrian, Burtless, \& Gruber, 1994; Nyce, Schieber, Shoven, Slavov, \& Wise, 2013; Robinson \& Clark, 2010; Rogowski \& Karoly, 2000; Rust \& Phelan, 1997; Scholz \& Seshadri, 2013; Shoven \& Slavov, 2014; Strumpf, 2010). Nearly all of these papers find that the availability of insurance that is not contingent upon one's own continued work - from Medicare, as a dependent on a spouse's policy, from coverage intended for early retirees, or from COBRA - significantly increases the probability of retirement.

Surprisingly, in light of this literature, research to date on the effect of the ACA on older American's labor supply shows little effect. In our own earlier work (Levy, Buchmueller, and 
Nikpay 2016a) we analyzed trends in retirement using data from the basic monthly CPS through mid-2016 and found no significant increase in retirement in 2014, either overall or in Medicaid expansion states compared to nonexpansion states. We also found no increase in part-time work among older workers. Gustman et al. (2018), using data from the Health and Retirement Study, find no evidence that the ACA increased either the propensity to retire or workers' expectations about retirement. As already noted, however, the lack of an effect may be because older workers were reluctant to leave stable jobs with health insurance for relatively new insurance options created by the ACA. Ongoing political uncertainty about the future of those options may have exacerbated these concerns. In either case, we would expect workers' responsiveness to the availability of these new health insurance options to increase as they become more established and familiar.

\section{Overview of innovations relative to existing work, data, and research plan}

In Levy et al. (2016a), we used data from the basic monthly Current Population Survey through June 2016 to show that there was no change in 2014 in the fraction of older adults who were retired or the fraction of older workers who worked part-time, either nationally or in states that implemented the ACA's Medicaid expansion compared with those that did not. The current draft of the paper extends this analysis using basic monthly CPS data through April 2018, the most recent available. In addition, we extend the analysis in a number of ways. We use the Annual Social and Economic Supplement (ASEC) to the CPS, available once each year, to conduct analyses for subgroups defined by education and health status. (Education is available in the basic monthly CPS, but health status is not.) We use the Integrated Public Use Microdata Series (IPUMS) version of the matched year-over-year CPS-ASEC (described in detail in Rivera Drew et al. 2014) to estimate trends in labor force transitions for older Americans over the 
period 2008 through 2017; this allows us to measure, for example, whether the rate at which older workers exit the labor force increased after 2014, either overall or in Medicaid expansion states compared to nonexpansion ones. We also use longitudinal data from the Health and Retirement Study (HRS) from 2004 through 2016 to estimate trends in labor force transitions. Finally, we use data from the American Community Survey (ACS) from 2008 through 2016 to confirm that there were sharp increases in private nongroup insurance coverage and Medicaid among individuals ages 50 through 64 , which rules out the possibility that older Americans were simply not aware of these programs. Table 1 summarizes the datasets used in our analyses and the different outcomes examined using each.

\section{Defining the sample}

In the basic monthly CPS, the CPS-ASEC, and the ACS, our sample is restricted to individuals ages 50 through 64 . For analyses of transitions in the matched CPS-ASEC, the sample is restricted to individuals ages 50 through 63 in the first year of the match in order to avoid the Medicare age eligibility threshold of 65 in the second year of the match. In the HRS, the sample is restricted to individuals ages 55 through 62 in the first year of the match. The upper age restriction of 62 is to avoid the Medicare age eligibility threshold of age 65 in the subsequent wave, since HRS interviews are conducted at approximately two-year intervals. The lower age restriction of 55 is because the HRS sample is "refreshed" every six years, with a lower age cutoff for each new cohort of 51. As a result, constructing a consistent sample across multiple HRS waves requires dropping individuals younger than 55 .

\section{Definition of key variables}

Medicaid expansion: We consider the 25 states that increased Medicaid eligibility for childless adults to 138 percent of poverty on January 1,2014, to be expansion states in our 
analysis. Ten of these (AZ, CA, CT, DC, DE, HI, MA, MN, NY, and VT) already had relatively generous Medicaid coverage prior to 2014, while the other 15 did not (AR, CO, IA, IL, KY, MD, ND, NJ, NM, NV, OH, OR, RI, WA, and WV). However, all of them experienced significant increases in Medicaid coverage for adults starting in 2014. We count the 19 states that have not implemented Medicaid expansion as of July 2018 to be nonexpansion states (AL, FL, GA, ID, KS, ME, MO, MS, NC, NE, OK, SC, SD, TN, TX, UT, VA, WI, and WY); note that two of these states, Virginia and Maine, have in fact voted to expand Medicaid, but have not yet implemented these expansions. The remaining seven states (MI, NH, AK, IN, PA, LA, and MT) expanded Medicaid mid-year during 2014, 2015, or 2016 and are, therefore, excluded from the current analysis, which in practice means dropping 12 percent of observations on older adults. Table 2 summarizes how we code Medicaid expansion status in our analyses.

Labor market and retirement outcomes: We focus primarily on four labor market outcomes that are available in the CPS-ASEC, the basic monthly CPS, and the HRS: participating in the labor force; doing any work for pay; working full-time, conditional on doing any work for pay; and being retired. In the CPS, we rely on the standard Bureau of Labor Statistics (BLS) definitions of these constructs, as reflected in the CPS variables. In the HRS, we rely on selfreported employment status at the time of the survey. We define full time work as 30 hours or more per week, which is consistent with the ACA's definition of full-time workers for whom large employers must provide affordable coverage or face a tax penalty. For the CPS-ASEC, we also analyze whether the individual reported receipt of Social Security income in the calendar year prior to the survey year.

Health insurance outcomes: We analyze trends over time in the fraction of older individuals who have four different types of health insurance: uninsured, Medicaid, private 
nongroup coverage, and employer-sponsored coverage. Note that these are not mutually exclusive (except for uninsured), since an individual might have, for example, both private nongroup coverage and employer-sponsored coverage at the same time. Individuals may have other sources of coverage as well - in particular, Medicare - for which we do not present results in this paper.

Other variables: All four datasets include basic demographic information including gender, race, ethnicity, marital status, and education. The CPS-ASEC and HRS also have self-reported health status (excellent/very good/good/fair/poor), which the basic monthly CPS and the ACS do not. In each dataset, we merge on the state-level unemployment rate in each month (basic monthly CPS) or year (CPS-ASEC, ACS, HRS), provided by BLS and obtained through FRED (https://fred.stlouisfed.org/). We use education and health status to define population subgroups most likely to have benefited from new health insurance options - specifically, individuals with a high school education or less, and individuals in fair or poor health - to see if these subgroups may have experienced labor supply changes not evident in the older population as a whole. We also test below for differences in economic and demographic variables across expansion and nonexpansion states over time to assess the validity of the quasi-experimental comparison between expansion and nonexpansion states.

\section{Results}

Trends in economic and demographic variables/validity of the comparison across expansion and nonexpansion states:

We begin with results from the basic monthly CPS, comparing trends in covariates over time to assess the face validity of the comparison of trends. Figure 1 presents trends in four of these covariates. It is evident from Figure 1 that both the fraction of the population who are 
nonwhite or Hispanic and the fraction who are married women are very similar across the two groups of states; the fraction nonwhite or Hispanic increases steadily over time, while the fraction that is married and female fluctuates with an overall decline. In terms of education, nonexpansion states have a higher share of residents with a high school education or less, but the trends over time across the two groups of states are very stable and the difference between them at any point in time is not significant (as is suggested by the overlapping confidence intervals in the figure). Finally, the unemployment rate: in both groups of states, unemployment rose sharply during the recession. Residents of expansion states faced, on average, slightly higher state-level unemployment than residents of nonexpansion states beginning around 2010, although this difference is not significant at any point in time. Unemployment gradually returned to prerecession levels, remaining slightly higher in expansion states than nonexpansion states, and this difference is significant in 2017. Overall, then, these trends in covariates mostly support the idea that (a) there is no big discontinuity in 2014 that might explain overall changes at that point and (b) any differences between expansion and nonexpansion states are quite stable over time, suggesting that nonexpansion states provide a valid "counterfactual" for what might have happened in expansion states in the absence of expansion.

\section{Trends in health insurance coverage}

Figure 2 presents unadjusted trends in health insurance coverage rates, using ACS data. From 2008 to 2013, the percentage of 50- to 64-year-olds with Medicaid coverage was nearly identical in the two groups of states. In 2014, there was a significant increase in Medicaid enrollment in expansion states, but not in nonexpansion states. That same year, private nongroup coverage increased in both groups of states, though more so in nonexpansion states. It does not appear that the ACA coverage expansions affected employer-sponsored insurance in either set of 
states. The net effect of these changes is a clear drop in uninsurance in both types of states in 2014, with a slightly larger change in expansion states.

These patterns are very similar, although levels of uninsurance are higher, if we restrict the sample to below-median education (Figure 3). The fact that both expansion and nonexpansion states experienced similar drops in overall uninsurance in 2014 and later suggests that "treatment" effect of Medicaid expansion, relative to not expanding, is minimal and consists primarily of the type of insurance (public versus private) people gained rather than a greater increase in the overall level of coverage. Thus, in terms of labor supply outcomes, it is important that we look for changes in trends within each group of states in 2014 and not just the possibility of a differential trend in expansion versus nonexpansion states.

\section{Trends in labor market outcomes}

Figure 4 presents trends in four key outcomes using data from the basic monthly CPS: labor force participation, working for pay, working full time conditional on working at all, and being retired. For each of these outcomes, there is no discernible break in 2014 for either expansion or nonexpansion states. Nor is there any evidence of a relative change in one group of states versus the other. In some cases in which the trends appear to be changing differentially over time (e.g., the gap in the fraction of workers who are full-time appears to narrow after 2014), it is not in the expected direction: Older workers in expansion states become (insignificantly) more likely to work more than 30 hours, compared with their counterparts in nonexpansion states. Figure 5 shows the same trends for individuals with a high school education or less and no significant patterns are evident there either.

Figure 6 shows three of the same outcomes (labor force participation, working full time conditional on working at all, and being retired) using data from the CPS-ASEC, plus a fourth 
outcome not available in the basic monthly CPS, receipt of Social Security income in the prior calendar year. The three outcomes that overlap with the basic monthly CPS look very similar. We do not report results for "any work" in the CPS-ASEC in the interest of keeping the tables relatively simple. The results are very similar to those for "any work" in the basic monthly CPS (Figure 4). Figures 7 and 8 show similar trends for subgroups with a high school education or less (Figure 7) or in fair or poor health (Figure 8) and they too show no significant changes in 2014 either overall or in expansion versus nonexpansion states.

\section{Trends in labor market transitions}

The results so far suggest no labor supply response to the ACA; however, the outcomes analyzed so far have all been stocks (e.g. the probability that a given individual is in the labor force at a point in time), which may be slow to adjust compared to flows (e.g. the probability that a given individual in the labor force at time 1 is not in the labor force at time 2). The next set of analyses estimates changes in the probability of different transitions, using data from both the matched CPS-ASEC and the HRS. Note that the two datasets measure transitions over different time periods. The matched CPS-ASEC data reflection transitions over a twelve-month period; for example, does an individual who is working for pay in March of 2012 report that they are still working for pay in March of 2013? The HRS data, in contrast, are collected every two years; for example, the HRS would measure whether an individual who was working for pay at the time of their HRS interview in 2012 is still working for pay approximately 24 months later when they complete their $2014 \mathrm{HRS}$ interview. In both datasets, we present rates of entry into and exit from four different labor market states: participating in the labor force; working for pay; working 30 hours or more per week, conditional on working; and being retired. We present separate estimates for the full sample of older individuals (with age restrictions as described above); for 
the subset who have a high school education or less (approximately 40 percent of the sample); and for the subset who are in fair or poor health (about 20 percent of the sample). We present a full set of results for the matched CPS-ASEC (Figures 9 through 14) and then analogous results using HRS (Figures 15 through 20). Table 3 below lists the contents of the data, outcomes, and subsample used for each of the figures in the table.

Beginning with the matched CPS-ASEC results, one-year rates of entry into the labor force fluctuate around 10 percent for older individuals in both expansion and nonexpansion states, with no evident trend over time and no significant differences across the two groups of states (Figure 8, top-left graph). Rates of labor force exit and rates of entry into and exit from work also show no systematic trend over time or differences across expansion and nonexpansion states, as shown in the other three graphs in Figure 9. Figures 10 and 11 present the same outcomes for subsamples defined by having a high school education or less (Figure 10) or fair/poor health (Figure 11). None of the graphs in Figures 10 or 11 suggests a break in 2014 or a divergence in trends between expansion and nonexpansion states. Figures 12, 13, and 14 present matched CPSASEC results for two different types of outcomes: entry into and exit from full-time work, for workers, and entry into and exit from retirement. None of these figures suggests any effect of the ACA on these outcomes.

Figures 15 through 20 present analogous results using two-year transitions measured in HRS data. These results, too, largely suggest no impact of the ACA - that is, no break in trend in 2014 and no divergence in trend between expansion and nonexpansion states - with one exception, shown in Figure 17. Among individuals in fair or poor health, trends in the probability of labor force entry were very similar through the 2012/2014 transition; however, in the 2014/2016 transition, the probability of entering the labor force was significantly higher for those 
living in states that expanded Medicaid than those that did not. The trends in the probability of entry into work show a similar pattern. This is, of course, not consistent with the idea that the ACA reduced seniors' labor market activity; on the contrary, if we accept this result at face value, it implies that Medicaid expansion increased labor force participation and work for older individuals who were in fair or poor health.

\section{Age profiles of labor force outcomes}

A possible criticism of the analyses presented so far is that the age group of 50 through 64 , while consistent with the Census Bureau's definition of individuals who may be coded as retired in the CPS, is in fact overly broad since it pools individuals in their early 60s whose labor supply may be highly responsive to the availability of new health insurance alternatives with those in their 50s who remain more strongly attached to the labor force. Individuals ages 62 through 64 , who are eligible to claim early Social Security benefits but are not yet age-eligible for Medicare, may be the most likely to reduce labor supply in response to the new ACA programs. The analyses so far also discard information on individuals ages 65 and older, who are not eligible for the ACA programs but provide a potentially informative counterfactual for those younger than age 65 .

In order to address these concerns, we next present a set of age profiles for different outcomes, for expansion and nonexpansion states, in three periods corresponding to before and after the implementation of the ACA coverage provisions: 2008 through 2010, 2011 through 2013, and 2015 through 2017. (We omit 2014 as a transition year.) We use the CPS-ASEC for these analyses; the basic monthly CPS yields very similar results, but would not allow us to subset the sample by health status or to analyze receipt of Social Security income, so we report results from the CPS-ASEC. Figure 15 shows the fraction of the sample that is in the labor force 
by single year of age in these three time periods. The figure shows that the probability of labor force participation declines with age, first gradually and then more rapidly, in both expansion and nonexpansion states both before and after 2014. In a nutshell, the lines representing the three time periods are right on top of each other; the only visual differences (which are not significant) are for individuals older than 65 . The same is true for samples defined by low education or fair/poor health status (Figures 16 and 17).

Age profiles for the probability of full-time work among workers generally show the same (lack of) results (Figures 18 through 20), as do age profiles for the probability of having received any Social Security income (Figures 21 through 23).

\section{Discussion}

We fail to find any effect of the Affordable Care Act's coverage provisions on the labor supply of older adults. How can this be, when the earlier literature consistently found large effects of coverage on retirement? One possibility is that even though the ACA coverage provisions have now been in effect for more than four years, the political uncertainty surrounding these programs continues to discourage older workers from counting on them when making career decisions. After the failure of very high-profile attempts to repeal the entire law in the summer of 2017, the current administration continues to take steps that create uncertainty about the law's future. For example, in late 2017 the Department of Health and Human Services announced its willingness to consider Medicaid work requirements, and older workers are not necessarily exempt from such requirements. In the case of marketplace coverage, the administration has taken a variety of steps - most recently, announcing the discontinuation of risk adjustment payments to health insurance plans - that guarantee that concerns about the stability of the nongroup market remain in the headlines. Whether the ACA will ever achieve 
political stability, and whether having done so it might lead older Americans to retire sooner, remains to be seen. 


\section{References}

Blau, D. M., \& Gilleskie, D. B. (2001). Retiree health insurance and the labor force behavior of older men in the 1990s. Review of Economics and Statistics, 83(1), 64-80.

Blau, D. M., \& Gilleskie, D. B. (2006). Health insurance and retirement of married couples. Journal of Applied Econometrics, 21(7), 935-953.

Blau, D. M., \& Gilleskie, D. B. (2008). The role of retiree health insurance in the employment behavior of older men. International Economic Review, 49(2), 475-514.

Fitzpatrick, M. D. (2014). Retiree health insurance for public school employees: Does it affect retirement? Journal of Health Economics, 38, 88-98.

French, E., \& Jones, J. B. (2011). The effects of health insurance and self-insurance on retirement behavior. Econometrica, 693-732.

French E, von Gaudecker H-M, and Jones JB. 2016. The Effect of the Affordable Care Act on the Labor Supply, Savings, and Social Security of Older Americans. MRRC Working Paper 2016-354.

Gooptu, A., Moriya, A. S., Simon, K. I., \& Sommers, B. D. (2016). Medicaid Expansion Did Not Result In Significant Employment Changes Or Job Reductions In 2014. Health Affairs, 35(1), 111-118.

Gruber, J., \& Madrian, B. C. (1995). Health-Insurance Availability and the Retirement Decision. Am Econ Rev, 938-948.

Gruber, J., \& Madrian, B. C. (1996). Health insurance and early retirement: evidence from the availability of continuation coverage Advances in the Economics of Aging (pp. 115-146): University of Chicago Press.

Gustman, A. L., \& Steinmeier, T. L. (1994). Employer-provided health insurance and retirement behavior. Industrial \& Labor Relations Review, 48(1), 124-140.

Gustman, Alan L., Thomas L. Steinmeier, and Nahid Tabatabai. 2018. "The Affordable Care Act as Retiree Health Insurance: Implications for Retirement and Social Security claiming." Journal of Pension Economics \& Finance (2018): 1-35. 
.Harris E, Mok S. How CBO Estimates the Effects of the Affordable Care Act on the Labor Market. Congressional Budget Office Working Paper Series 2015-09; 2015 Dec.

Johnson, R. W., Davidoff, A. J., \& Perese, K. (2003). Health insurance costs and early retirement decisions. Industrial \& Labor Relations Review, 56(4), 716-729.

Kaestner, R., Garrett, B., Chen, J., Gangopadhyaya, A. and Fleming, C., 2017. Effects of ACA Medicaid expansions on health insurance coverage and labor supply. Journal of Policy Analysis and Management, 36(3), pp.608-642.

Leiserson, G. (2013). Essays on the Economics of Public Sector Retirement Programs. (Ph.D.), Massachusetts Institute of Technology, Cambridge, MA.

Leung P, Mas A. Forthcoming. Employment Effects of the ACA Medicaid Expansions. Industrial Relations.

Levy, Helen, Thomas C. Buchmueller, and Sayeh Nikpay. 2016a. "Health Reform and Retirement.” The Journals of Gerontology: Series B 73, no. 4 (2016): 713-722.

Levy H, Buchmueller TC, Nikpay S. 2016b. Health Reform and Health Insurance Coverage of Early Retirees. MRRC Working Paper WP 2016-343.

Long, S. K. (2008). On the road to universal coverage: impacts of reform in Massachusetts at one year. Health Affairs, 27(4), w270-w284.

Lumsdaine, R. L., Stock, J. H., \& Wise, D. A. (1996). Why are retirement rates so high at age 65? Advances in the Economics of Aging (pp. 61-82): University of Chicago Press.

Madrian, B. C., \& Beaulieu, N. (1998). Does Medicare Eligibility Affect Retirement? Inquiries in the Economics of Aging (pp. 109-131): University of Chicago Press.

Madrian, B. C., Burtless, G., \& Gruber, J. (1994). The effect of health insurance on retirement. Brookings Papers on Economic Activity, 181-252.

Mulligan CB. 2015. Side Effects and Complications: The Economic Consequences of Healthcare Reform. University of Chicago Press.

Nyce S, Schieber SJ, Shoven JB, Slavov SN, Wise DA. 2013. Does Retiree Health Insurance Encourage Early Retirement? Journal of Public Economics. 2013 Aug 31;104:40-51. 
Nyce, S., Schieber, S. J., Shoven, J. B., Slavov, S. N., \& Wise, D. A. (2013). Does retiree health insurance encourage early retirement? Journal of Public Economics, 104, 40-51.

Rivera Drew, J.A., Flood, S. and Warren, J.R., 2014. Making full use of the longitudinal design of the Current Population Survey: Methods for linking records across 16 months $\backslash \mathrm{m}\{1\}$. Journal of economic and social measurement, 39(3), pp.121-144.

Robinson, C., \& Clark, R. (2010). Retiree health insurance and disengagement from a career job. Journal of Labor Research, 31(3), 247-262.

Rogowski, J., \& Karoly, L. (2000). Health insurance and retirement behavior: evidence from the health and retirement survey. Journal of Health Economics, 19(4), 529-539.

Rust, J., \& Phelan, C. (1997). How social security and medicare affect retirement behavior in a world of incomplete markets. Econometrica: Journal of the Econometric Society, 781-831.

Scholz, J. K., \& Seshadri, A. (2013). Health Insurance and Retirement Decisions. Michigan Retirement Research Center Research Paper(2013-292).

Shoven, J. B., \& Slavov, S. N. (2014). The role of retiree health insurance in the early retirement of public sector employees. Journal of Health Economics, 38, 99-108.

Strumpf, E. (2010). Employer-sponsored health insurance for early retirees: impacts on retirement, health, and health care. International journal of health care finance and economics, 10(2), 105-147.

United States Congressional Budget Office. 2014. "Labor Market Effects of the Affordable Care Act: Updated Estimates," Appendix C in The Budget and Economic Outlook: 2014 to 2024. 
Table 1: Data sources used in the analysis

\begin{tabular}{|c|c|c|c|c|}
\hline & $\begin{array}{l}\text { Basic monthly } \\
\text { Current } \\
\text { Population } \\
\text { Survey (CPS) }\end{array}$ & CPS-ASEC & $\begin{array}{l}\text { American } \\
\text { Community } \\
\text { Survey (ACS) }\end{array}$ & $\begin{array}{l}\text { Health and } \\
\text { Retirement } \\
\text { Study (HRS) }\end{array}$ \\
\hline $\begin{array}{l}\text { Most recent data as of } \\
\text { July } 2018\end{array}$ & April 2018 & March 2017 & 2016 & $\begin{array}{l}2016 \\
\text { Early Release }\end{array}$ \\
\hline Periodicity & $\begin{array}{l}\text { Monthly; } \\
\text { aggregated to } \\
\text { quarterly for most } \\
\text { analyses }\end{array}$ & Annual & Annual & Biannual \\
\hline $\begin{array}{l}\text { Sample size of } \\
\text { individuals ages } 50-64\end{array}$ & $\sim 25,000 /$ month & 35,000/year & $\sim 650,000 /$ year & $\sim 6,000 /$ year $^{*}$ \\
\hline Outcomes analyzed & $\begin{array}{l}\text { Labor force } \\
\text { participation; } \\
\text { employment; full- } \\
\text { time status if } \\
\text { employed; } \\
\text { retirement }\end{array}$ & $\begin{array}{l}\text { Labor force } \\
\text { participation; } \\
\text { employment; } \\
\text { full-time status if } \\
\text { employed; } \\
\text { retirement; } \\
\text { receipt of Social } \\
\text { Security income } \\
\text { in past year }\end{array}$ & $\begin{array}{l}\text { Health insurance } \\
\text { coverage }\end{array}$ & $\begin{array}{l}\text { Labor force } \\
\text { participation; } \\
\text { employment; } \\
\text { full-time } \\
\text { status if } \\
\text { employed; } \\
\text { retirement }\end{array}$ \\
\hline
\end{tabular}

*Ages 55 through 64 only 
Table 2: Medicaid expansion versus nonexpansion states

\begin{tabular}{|c|c|c|c|}
\hline \multicolumn{2}{|l|}{$\begin{array}{l}\text { Expansion States } \\
(n=25)\end{array}$} & $\begin{array}{l}\text { Nonexpansion } \\
\text { states } \\
(\mathbf{n}=19)\end{array}$ & $\begin{array}{l}\text { Omitted from our analysis } \\
\text { because of late expansion } \\
(\mathbf{n}=7) \\
\text { Michigan (April 2014) }\end{array}$ \\
\hline $\begin{array}{l}\text { Expanded before } \\
\text { Jan. 2014: } \\
\text { Arizona } \\
\text { California } \\
\text { Connecticut } \\
\text { Delaware } \\
\text { Hawaii } \\
\text { Massachusetts } \\
\text { Minnesota } \\
\text { New York } \\
\text { Vermont } \\
\text { Washington, DC }\end{array}$ & $\begin{array}{l}\text { Expanded } \\
\text { Jan. 1, 2014: } \\
\text { Arkansas } \\
\text { Colorado } \\
\text { Illinois } \\
\text { Iowa } \\
\text { Kentucky } \\
\text { Maryland } \\
\text { Nevada } \\
\text { New Jersey } \\
\text { New Mexico } \\
\text { North Dakota } \\
\text { Ohio } \\
\text { Oregon } \\
\text { Rhode Island } \\
\text { Washington } \\
\text { West Virginia }\end{array}$ & $\begin{array}{l}\text { Alabama } \\
\text { Florida } \\
\text { Georgia } \\
\text { Idaho } \\
\text { Kansas } \\
\text { Maine }^{\text {b }} \\
\text { Mississippi } \\
\text { Missouri } \\
\text { Nebraska } \\
\text { North Carolina } \\
\text { Oklahoma } \\
\text { South Carolina } \\
\text { South Dakota } \\
\text { Tennessee } \\
\text { Texas } \\
\text { Utah } \\
\text { Virginia } \\
\text { Wisconsin } \\
\text { Wyoming }\end{array}$ & $\begin{array}{l}\text { Michigan (April 2014) } \\
\text { New Hampshire (Aug. 2014) } \\
\text { Pennsylvania (Jan. 2015) } \\
\text { Indiana (Feb. 2015) } \\
\text { Alaska (Sept. 2015) } \\
\text { Montana (Jan. 2016) } \\
\text { Louisiana (July 2016) }\end{array}$ \\
\hline \multicolumn{4}{|c|}{ Fraction of sample ages $50-64$ living in each group of states } \\
\hline $50.4 \%$ & & $37.4 \%$ & $12.2 \%$ \\
\hline
\end{tabular}

Sources: Kaiser Family Foundation website: http://kff.org/health-reform/state-indicator/state-activityaround-expanding-medicaid-under-the-affordable-care-act/, downloaded July 9, 2018; http://kff.org/medicaid/state-indicator/medicaid-income-eligibility-limits-for-other-nondisabled-adults/, downloaded July 9, 2018; Sommers et al. (2014).

Notes:

${ }^{a}$ Although New Jersey and Washington state also adopted early Medicaid expansion under the ACA, their early expansions were limited and involved primarily or exclusively shifting individuals who had previously been enrolled in state-financed programs onto Medicaid (Sommers et al. 2014). Full expansion of Medicaid eligibility to all individuals below 138 percent of poverty did not occur in these states until 2014. Therefore, we code them as having expanded Medicaid in January 2014.

${ }^{b}$ Maine and Virginia are both in the process of implementing Medicaid expansion but enrollment is not yet open. 
Table 3: Guide to Figures

\begin{tabular}{|c|c|c|c|}
\hline Fig. & Outcomes & Data & Sample \\
\hline 1 & $\begin{array}{l}\text { Covariates: Unemployment rate, } \\
\text { education high school or less, } \\
\text { nonwhite/Hispanic, married } \\
\text { female }\end{array}$ & $\begin{array}{l}\text { CPS Basic } \\
\text { monthly }\end{array}$ & Ages 50-64 \\
\hline 2 & \multirow{2}{*}{$\begin{array}{l}\text { Health insurance outcomes: } \\
\text { Uninsured, Medicaid, private } \\
\text { nongroup, employer coverage }\end{array}$} & \multirow[t]{2}{*}{ ACS } & Ages 50-64 \\
\hline 3 & & & Ages $50-64$, HS education or less \\
\hline 4 & \multirow{2}{*}{$\begin{array}{l}\text { Labor force participation, any } \\
\text { work, full-time work if working, } \\
\text { retired }\end{array}$} & \multirow{2}{*}{$\begin{array}{l}\text { CPS Basic } \\
\text { monthly }\end{array}$} & Ages 50-64 \\
\hline 5 & & & Ages $50-64$, HS education or less \\
\hline 6 & \multirow{3}{*}{$\begin{array}{l}\text { Labor force participation, full- } \\
\text { time work if working, retired, } \\
\text { receipt of Social Security }\end{array}$} & \multirow[t]{3}{*}{ CPS-ASEC } & Ages 50-64 \\
\hline 7 & & & Ages $50-64$, HS education or less \\
\hline 8 & & & Ages 50-64, fair/poor health \\
\hline 9 & \multirow{3}{*}{$\begin{array}{l}\text { Transitions in/out of labor force } \\
\text { and employment }\end{array}$} & \multirow{3}{*}{$\begin{array}{l}\text { Matched } \\
\text { CPS-ASEC }\end{array}$} & Ages 50-64 \\
\hline 10 & & & Ages $50-64$, HS education or less \\
\hline 11 & & & Ages 50-64, fair/poor health \\
\hline 12 & \multirow{3}{*}{$\begin{array}{l}\text { Transitions in/out of retirement } \\
\text { and, for workers, full-time status }\end{array}$} & \multirow{3}{*}{$\begin{array}{l}\text { Matched } \\
\text { CPS-ASEC }\end{array}$} & Ages 50-64 \\
\hline 13 & & & Ages $50-64$, HS education or less \\
\hline 14 & & & Ages 50-64, fair/poor health \\
\hline 15 & \multirow{3}{*}{$\begin{array}{l}\text { Transitions in/out of labor force } \\
\text { and employment }\end{array}$} & \multirow[t]{3}{*}{ HRS } & Ages 50-64 \\
\hline 16 & & & Ages $50-64$, HS education or less \\
\hline 17 & & & Ages 50-64, fair/poor health \\
\hline 18 & \multirow{3}{*}{$\begin{array}{l}\text { Transitions in/out of retirement } \\
\text { and, for workers, full-time status }\end{array}$} & \multirow[t]{3}{*}{ HRS } & Ages 50-64 \\
\hline 19 & & & Ages $50-64$, HS education or less \\
\hline 20 & & & Ages 50-64, fair/poor health \\
\hline 21 & \multirow{3}{*}{$\begin{array}{l}\text { Age profiles of labor force } \\
\text { participation }\end{array}$} & \multirow[t]{3}{*}{ CPS ASEC } & Ages 50-64 \\
\hline 22 & & & Ages $50-64$, HS education or less \\
\hline 23 & & & Ages 50-64, Fair/poor health \\
\hline 24 & \multirow{3}{*}{$\begin{array}{l}\text { Age profiles of full-time work } \\
\text { conditional on working }\end{array}$} & \multirow[t]{3}{*}{ CPS ASEC } & Ages 50-64 \\
\hline 25 & & & Ages $50-64$, HS education or less \\
\hline 26 & & & Ages 50-64, Fair/poor health \\
\hline 27 & \multirow{3}{*}{$\begin{array}{l}\text { Age profiles of Social Security } \\
\text { receipt }\end{array}$} & \multirow[t]{3}{*}{ CPS-ASEC } & Ages 50-64 \\
\hline 28 & & & Ages $50-64$, HS education or less \\
\hline 29 & & & Ages 50-64, FP health \\
\hline
\end{tabular}




\section{Figure 1}

Trends in characteristics by state Medicaid status Individuals ages 50-64
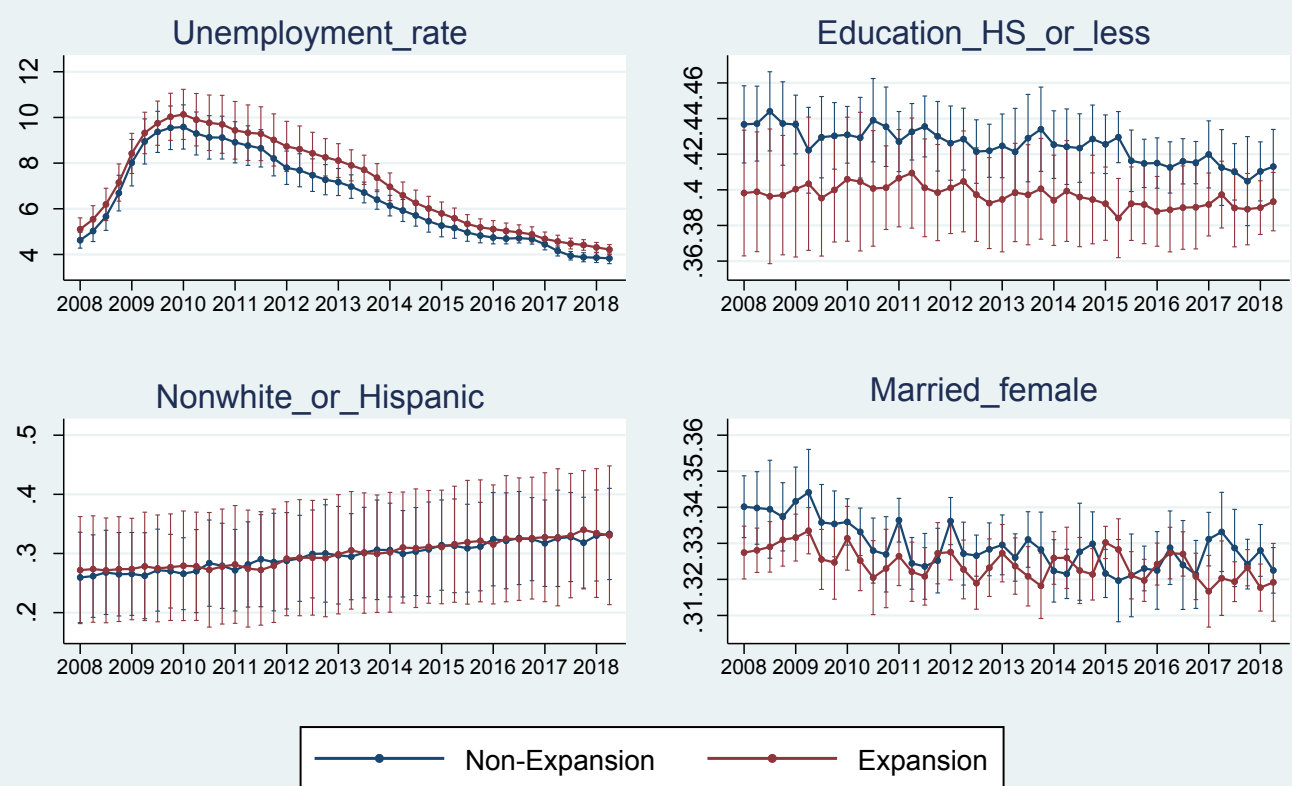

Source: CPS Basic Monthly

\section{Figure 2}

Trends in health insurance by state Medicaid status Individuals ages 50-64, All, not regression adjusted

Uninsured

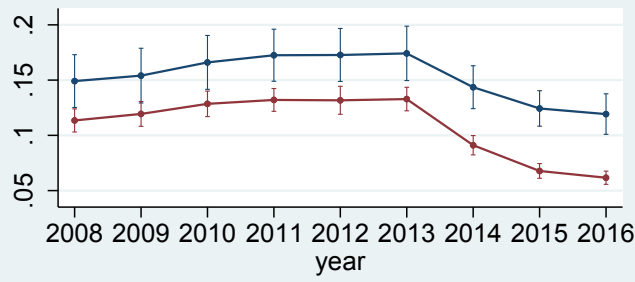

Non_Group

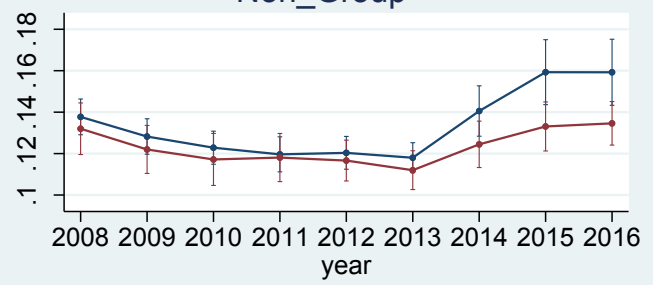

Medicaid

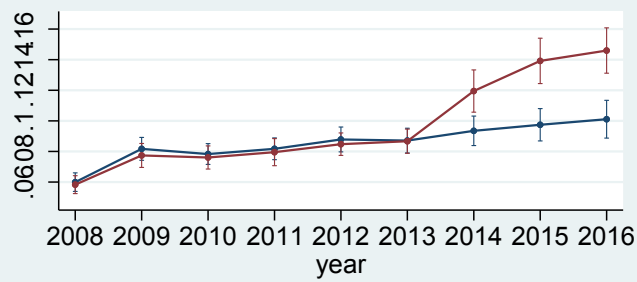

Employer

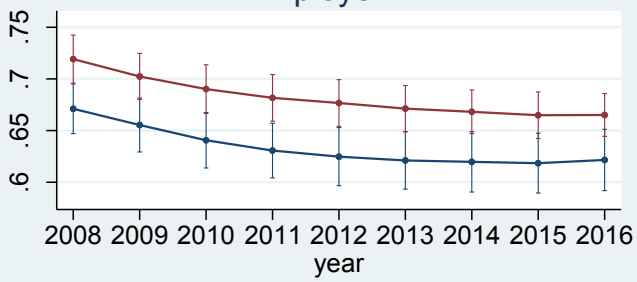

Non-Expansion

\section{Expansion}




\section{Figure 3}

Trends in health insurance by state Medicaid status Individuals ages 50-64, Education_HS_or_less, not regression adjusted

Uninsured

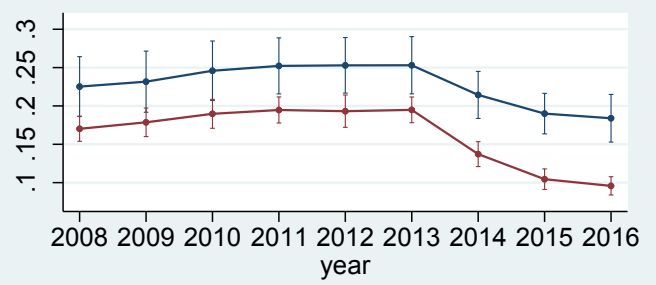

Non_Group

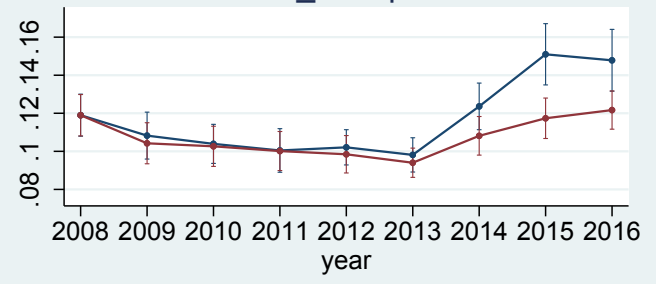

Non-Expansion
Medicaid

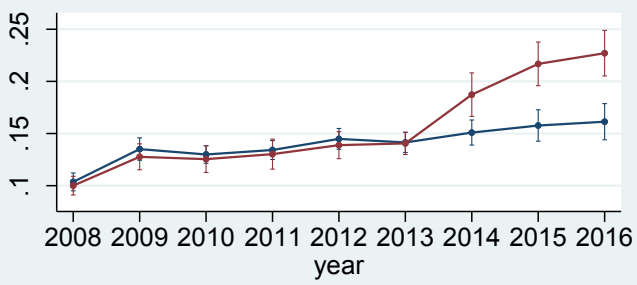

Employer

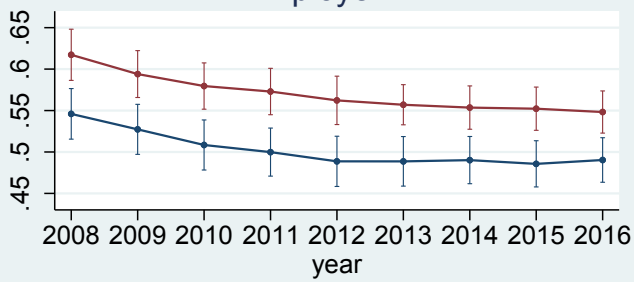

Source: ACS

Figure 4

Trends in labor market outcomes by state Medicaid status Individuals ages 50-64, Full_sample, not regression adjusted

In the labor force

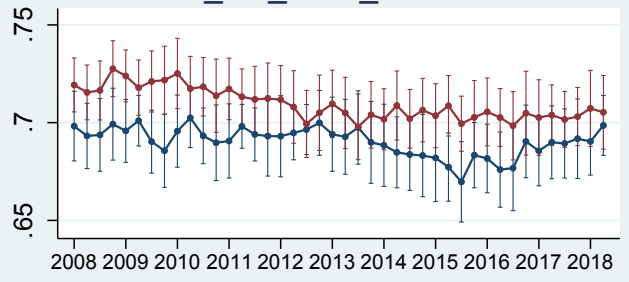

Full_time_if_worker

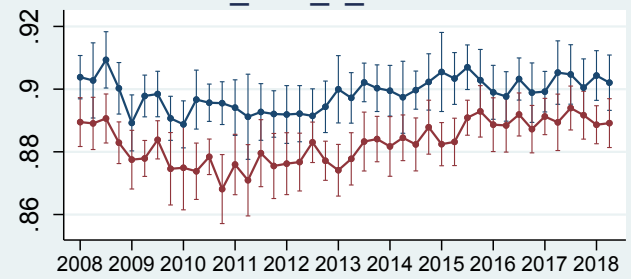

Working

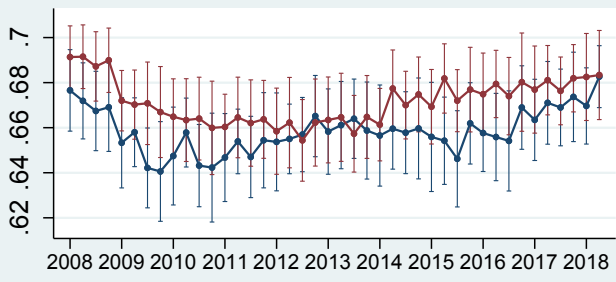

Retired

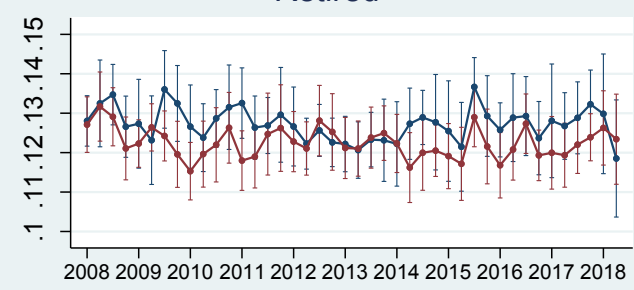

Non-Expansion

Expansion

Source: CPS Basic monthly 


\section{Figure 5}

Trends in labor market outcomes by state Medicaid status Individuals ages 50-64, Education_HS_or_less, not regression adjusted

In_the_labor_force

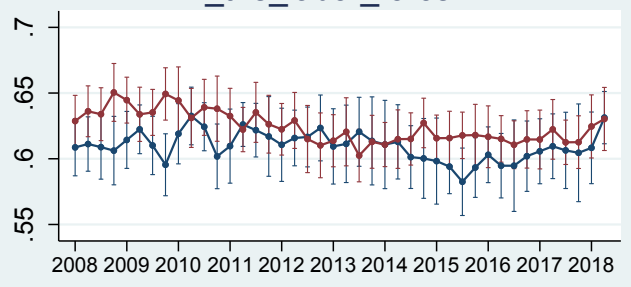

Full_time_if_worker

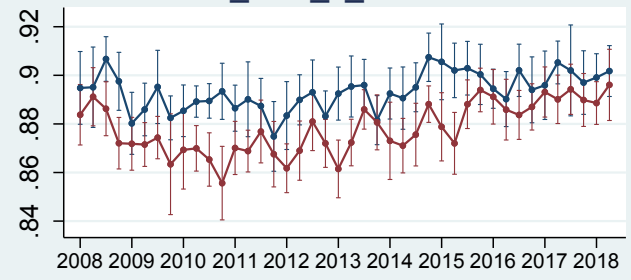

Working

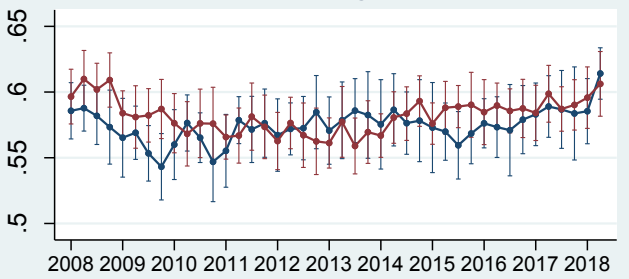

Retired

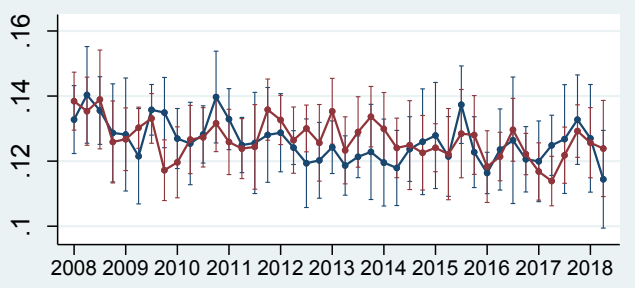

Non-Expansion

Expansion

Source: CPS Basic monthly

\section{Figure 6}

\section{Trends in labor market outcomes by state Medicaid status} Individuals ages 50-64, All, not regression adjusted
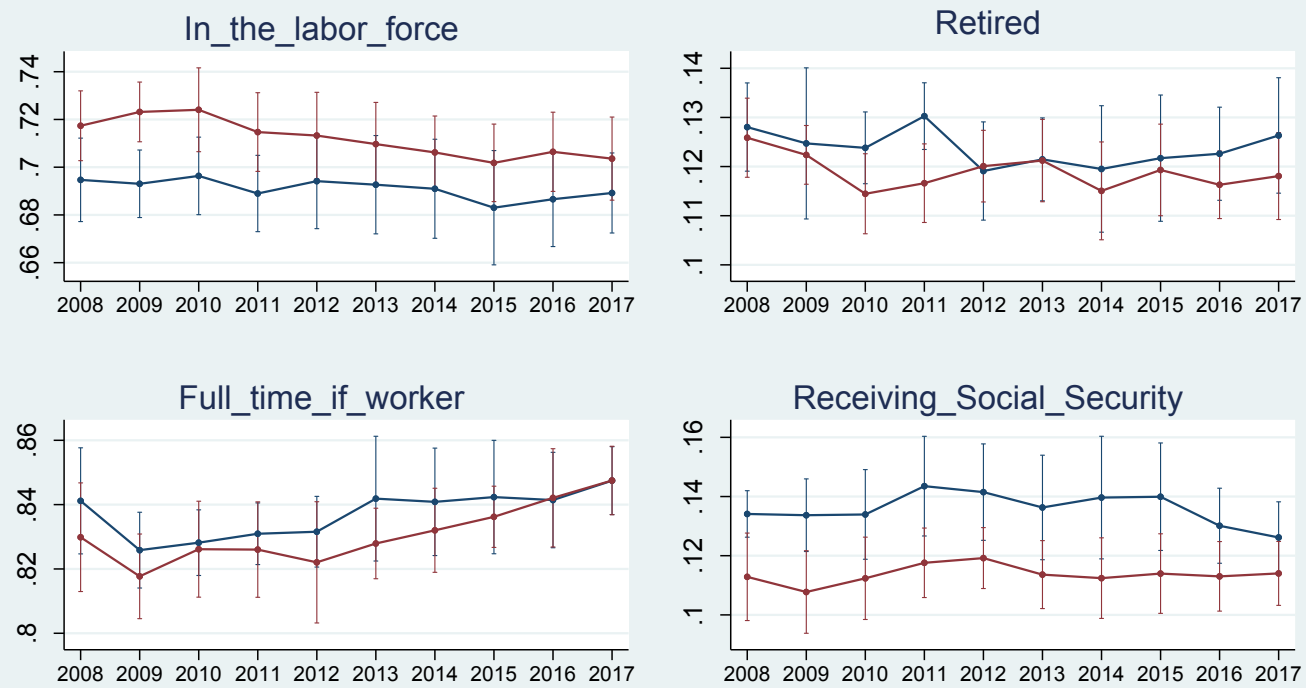

Non-Expansion Expansion

Source: CPS ASEC 


\section{Figure 7}

Trends in labor market outcomes by state Medicaid status Individuals ages 50-64, Education_HS_or_less, not regression adjusted

In_the_labor_force

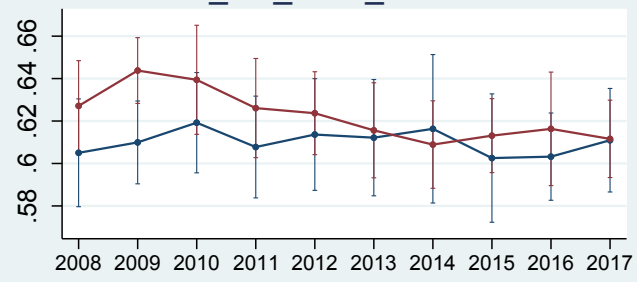

Full_time_if_worker

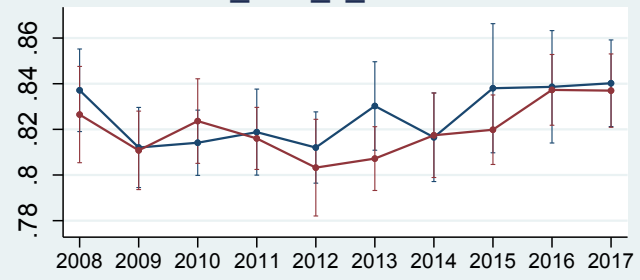

Retired
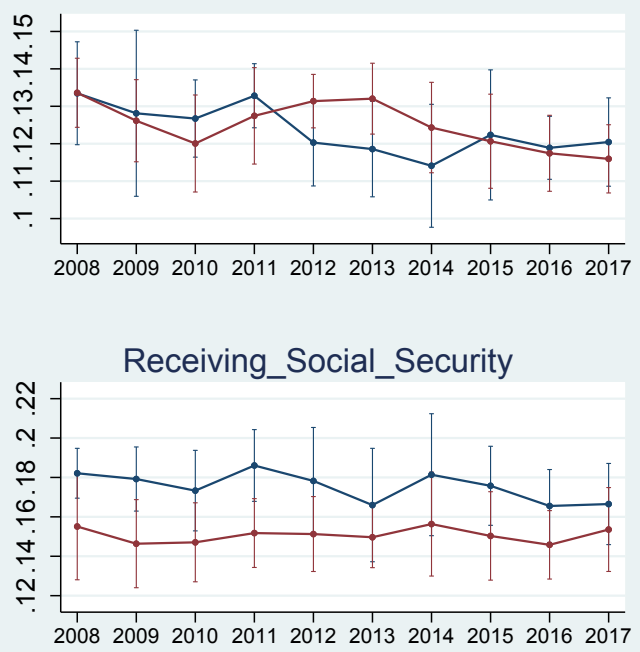

\section{Figure 8}

\section{Trends in labor market outcomes by state Medicaid status} Individuals ages 50-64, Health_fair_or_poor, not regression adjusted

In the labor force

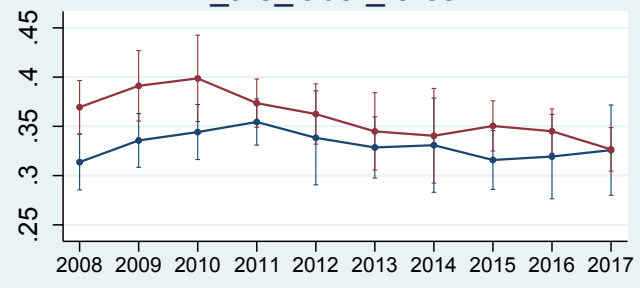

Full_time_if_worker

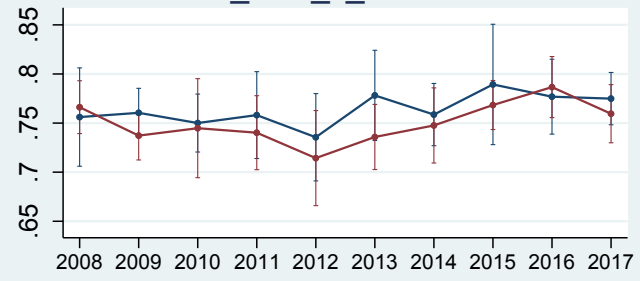

Retired

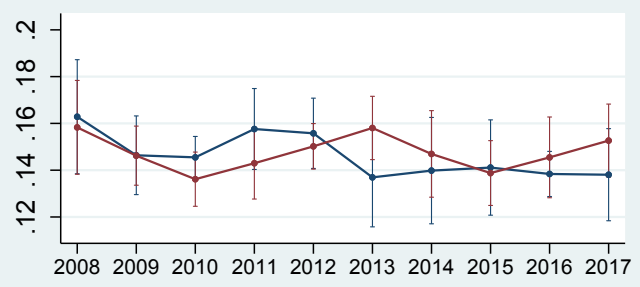

Receiving_Social_Security

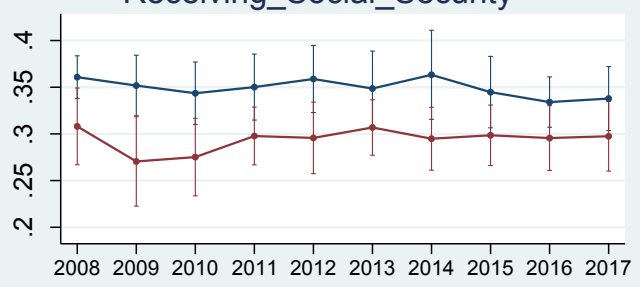

Non-Expansion Expansion

Source: CPS ASEC 


\section{Figure 9}

Trends in labor force participation and work transitions, by state Medicaid expansion status Individuals ages 50-63 at baseline, full_sample

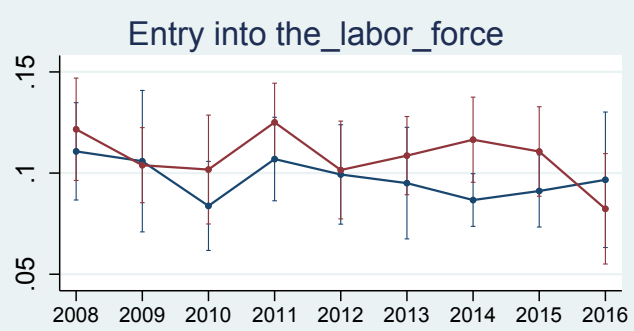

Exit from the_labor_force
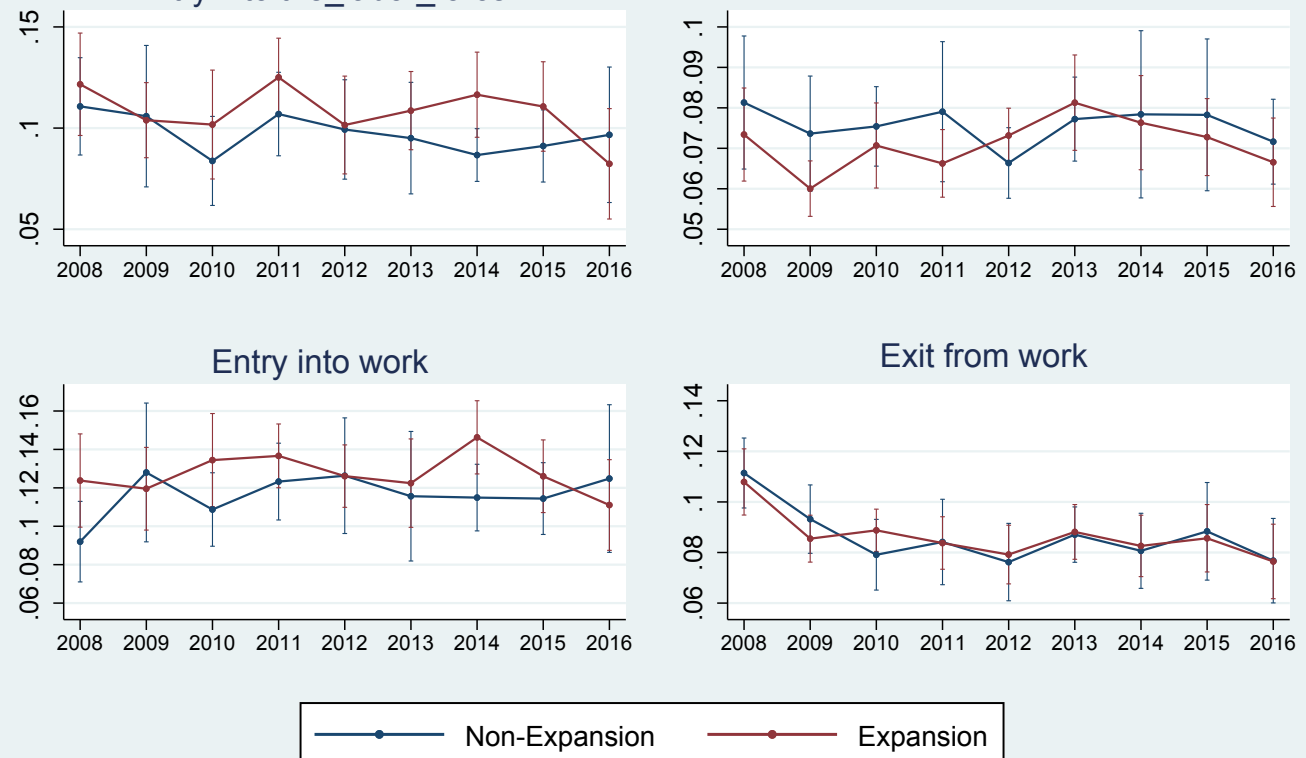

Expansion

Source: linked CPS ASEC

\section{Figure 10}

Trends in labor force participation and work transitions, by state Medicaid expansion status Individuals ages 50-63 at baseline, education_HS_or_less

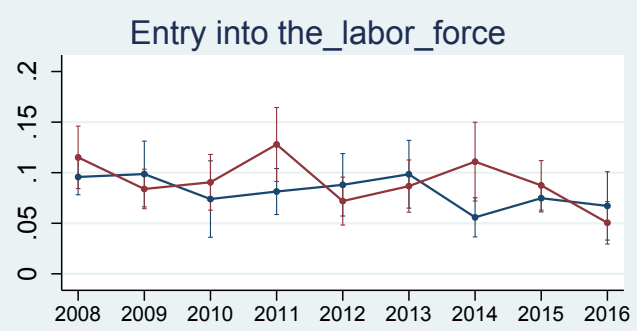

Exit from the_labor_force
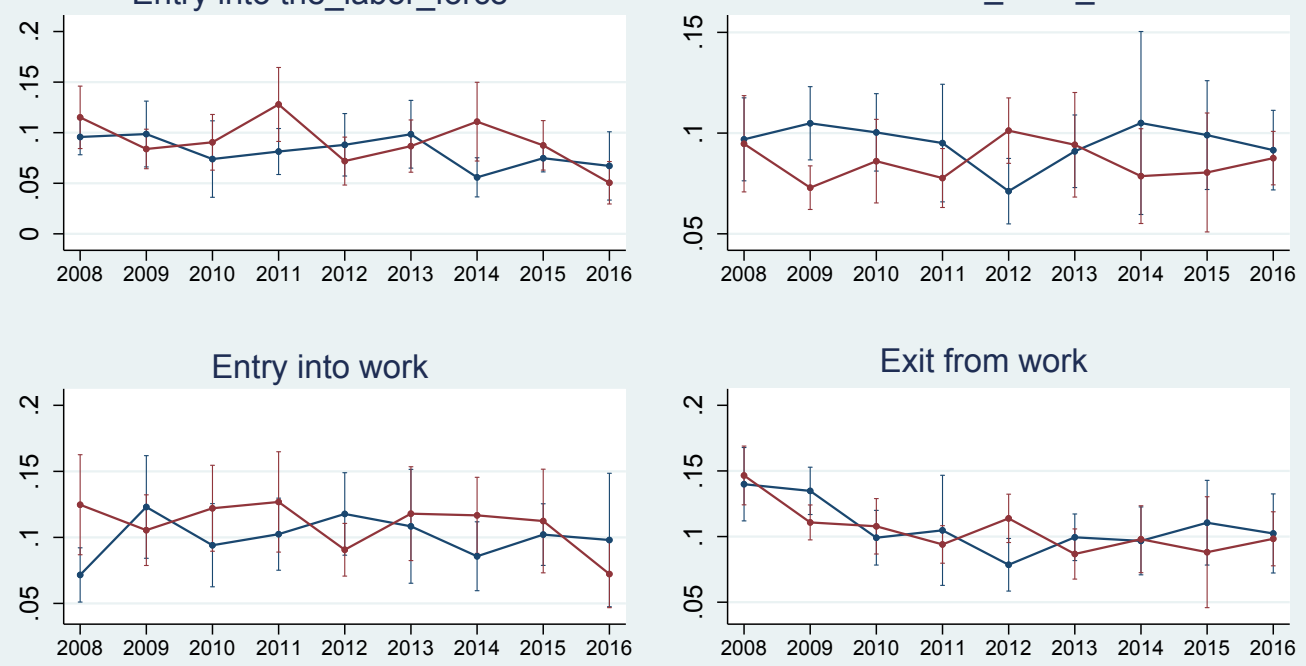

Non-Expansion

Expansion

Source: linked CPS ASEC 


\section{Figure 11}

Trends in labor force participation and work transitions, by state Medicaid expansion status Individuals ages 50-63 at baseline, health_fair_or_poor

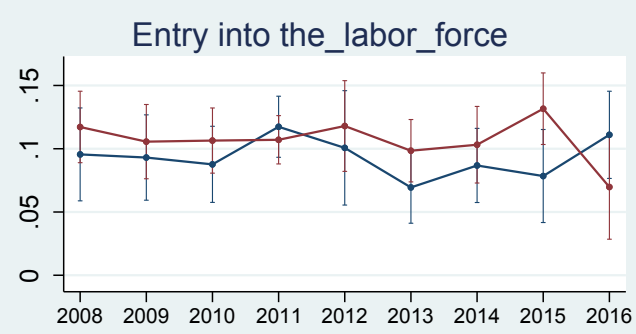

Exit from the_labor_force
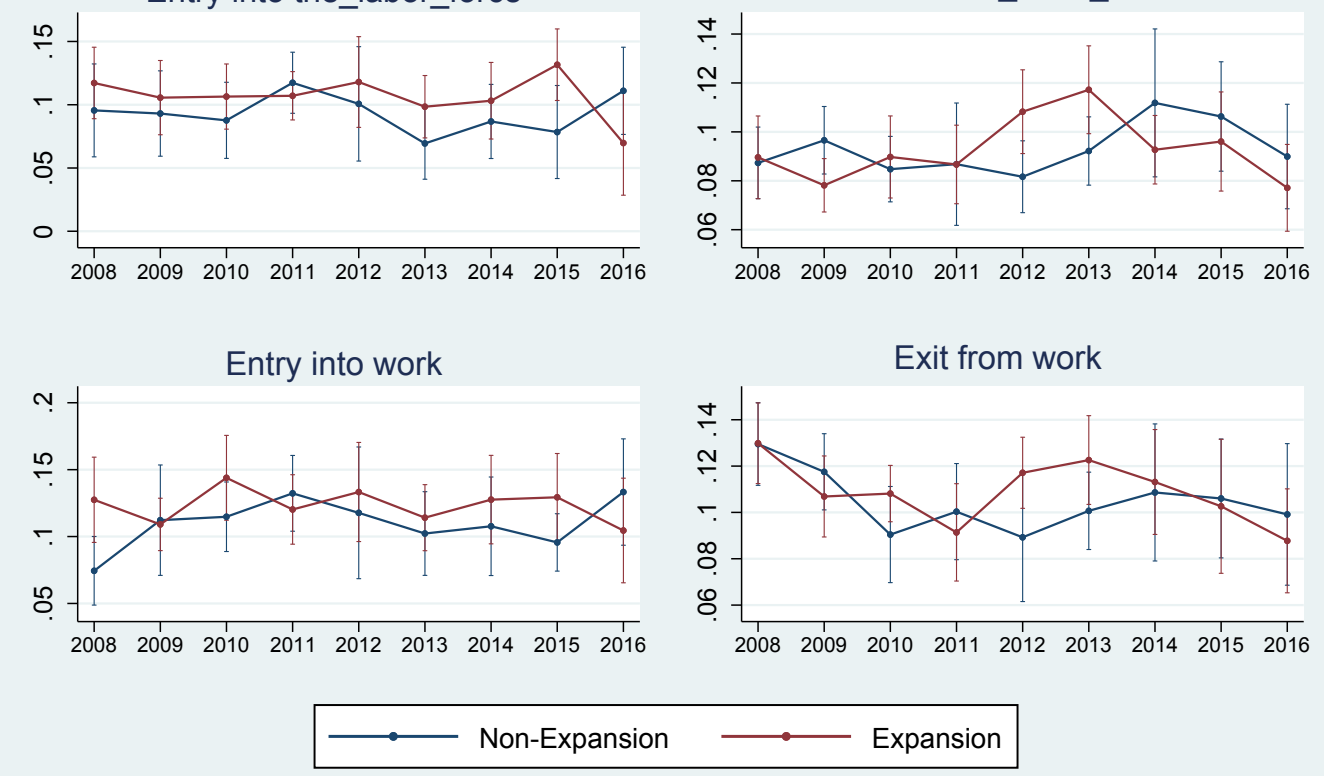

Source: linked CPS ASEC

\section{Figure 12}

Trends in full-time work and retirement transitions, by state Medicaid expansion status Individuals ages 50-63 at baseline, full_sample
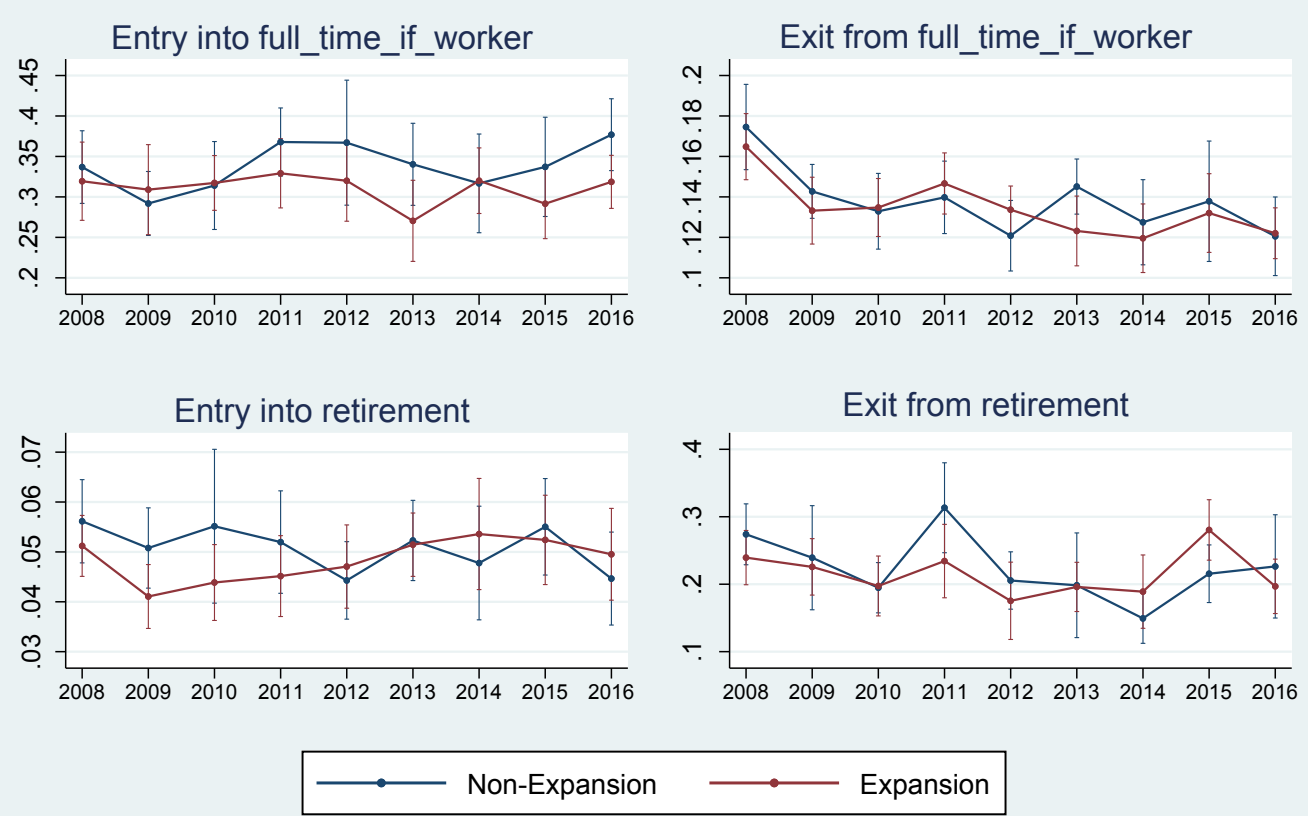

Source: linked CPS ASEC 


\section{Figure 13}

Trends in full-time work and retirement transitions, by state Medicaid expansion status Individuals ages 50-63 at baseline, education_HS_or_less
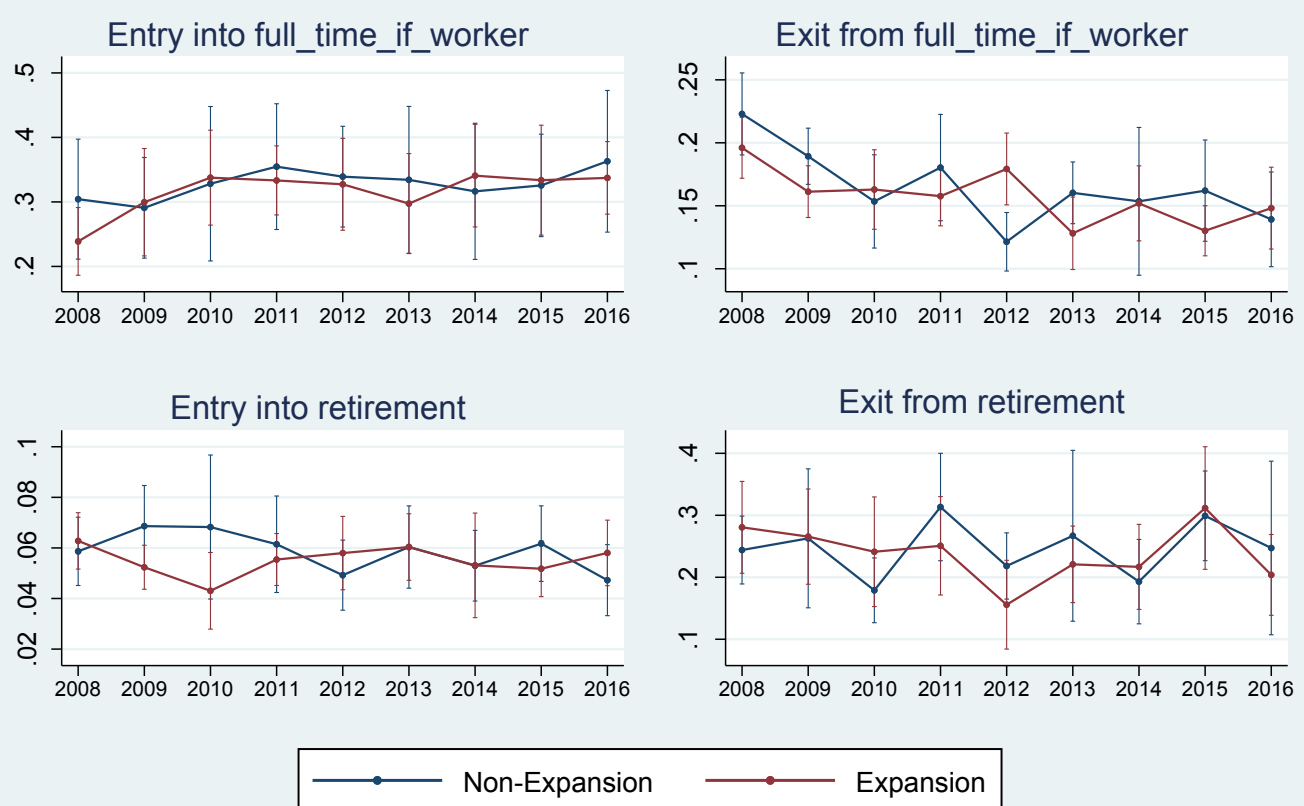

Expansion

Source: linked CPS ASEC

\section{Figure 14}

Trends in full-time work and retirement transitions, by state Medicaid expansion status Individuals ages 50-63 at baseline, health_fair_or_poor
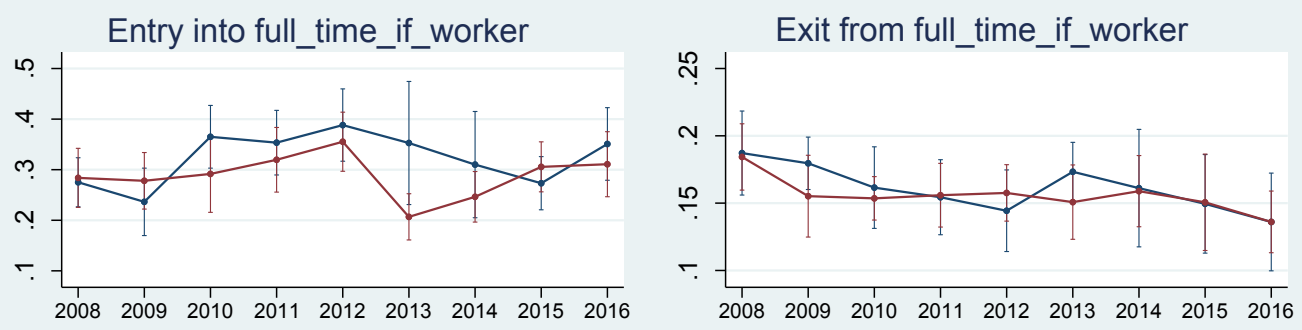

Entry into retirement

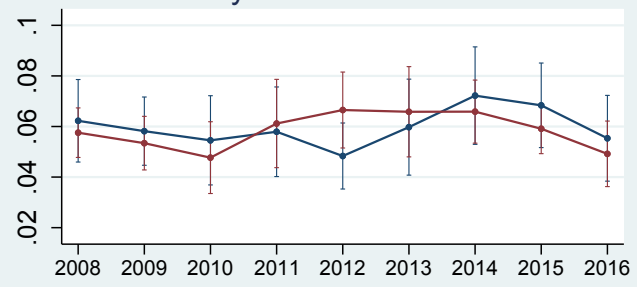

Exit from retirement

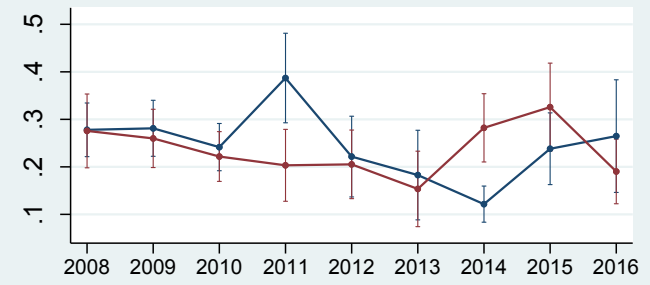

Non-Expansion

Expansion

Source: linked CPS ASEC 


\section{Figure 15}

Trends in labor force participation \& work transitions, by state Medicaid expansion status Individuals ages 55-62 at baseline,full_sample

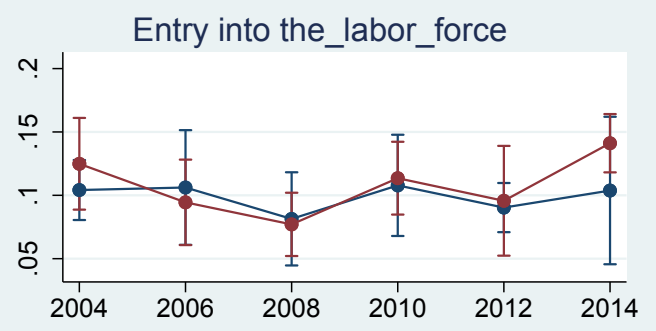

Exit from the_labor_force
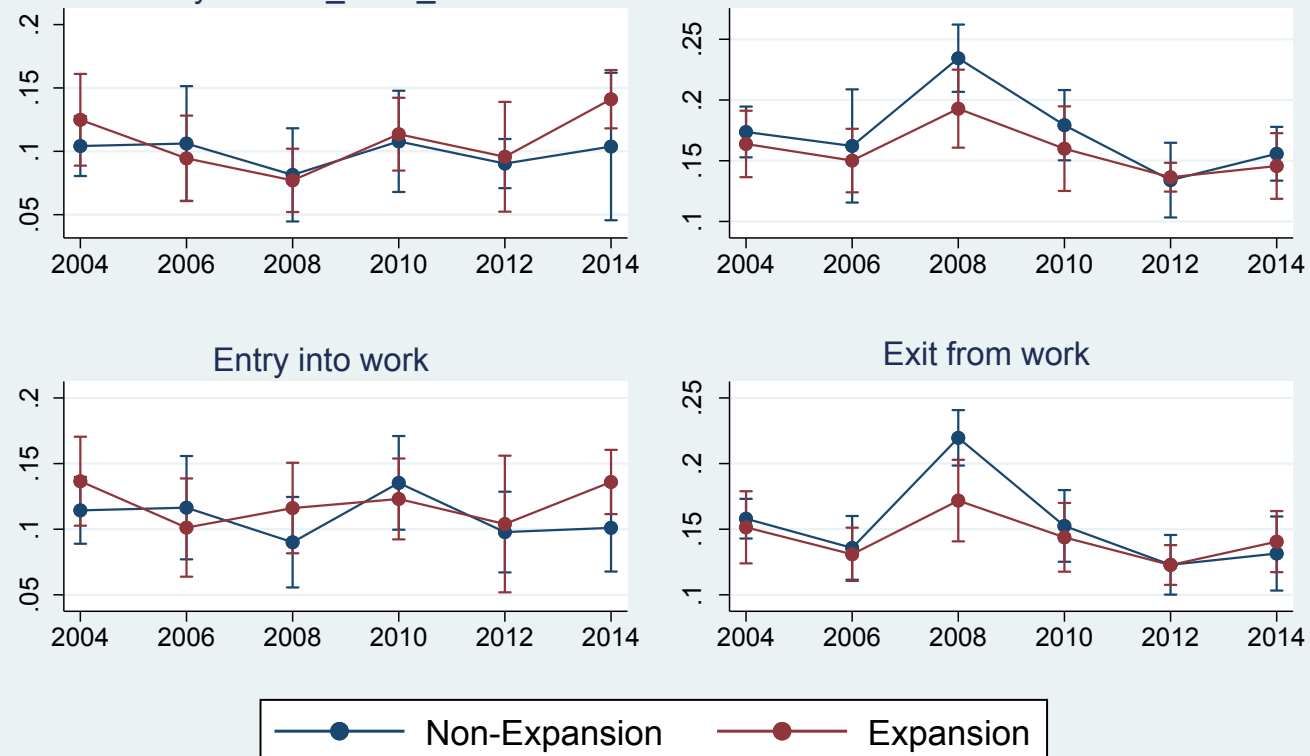

Source: Health and Retirement Study

\section{Figure 16}

Trends in labor force participation \& work transitions, by state Medicaid expansion status Individuals ages 55-62 at baseline,education_HS_or_less

Entry into the_labor_force

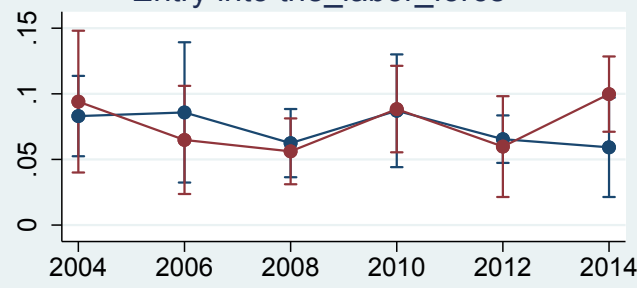

Entry into work

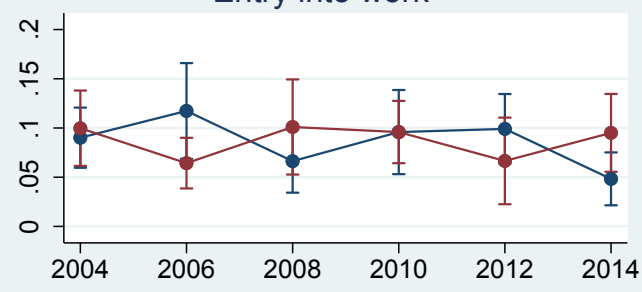

Exit from the_labor_force

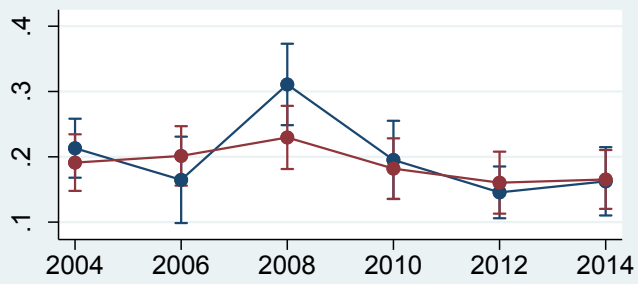

Exit from work

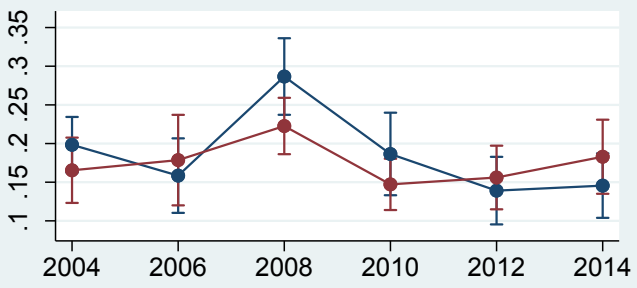

Source: Health and Retirement Study 


\section{Figure 17}

Trends in labor force participation \& work transitions, by state Medicaid expansion status Individuals ages 55-62 at baseline,health_fair_or_poor

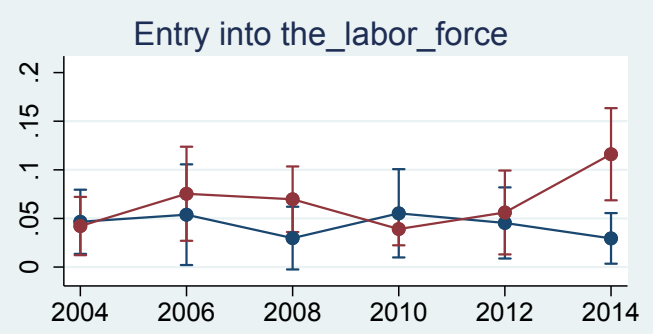

Exit from the_labor_force

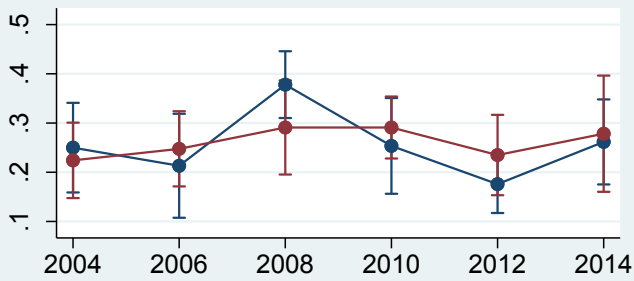

Entry into work

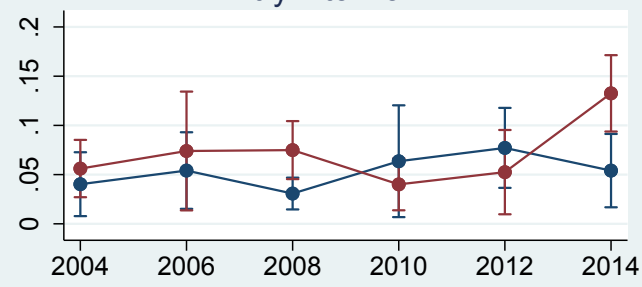

Exit from work
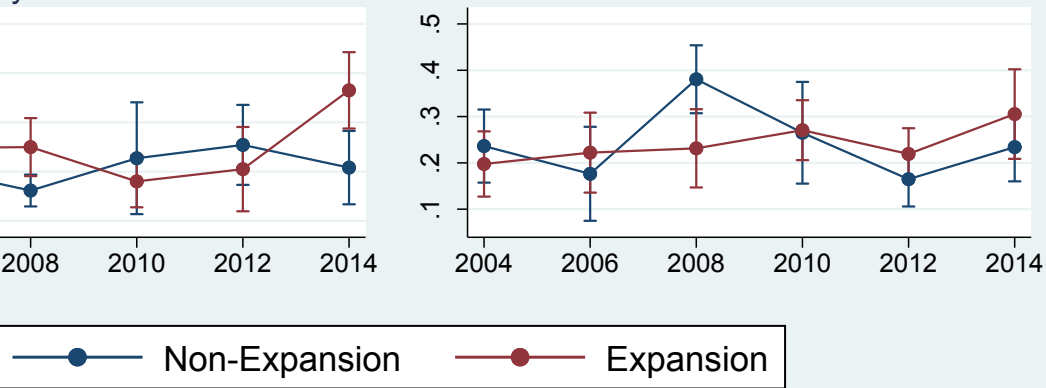

Source: Health and Retirement Study

\section{Figure 18}

Trends in full-time work and retirement transitions, by state Medicaid expansion status Individuals ages 55-62 at baseline, full_sample
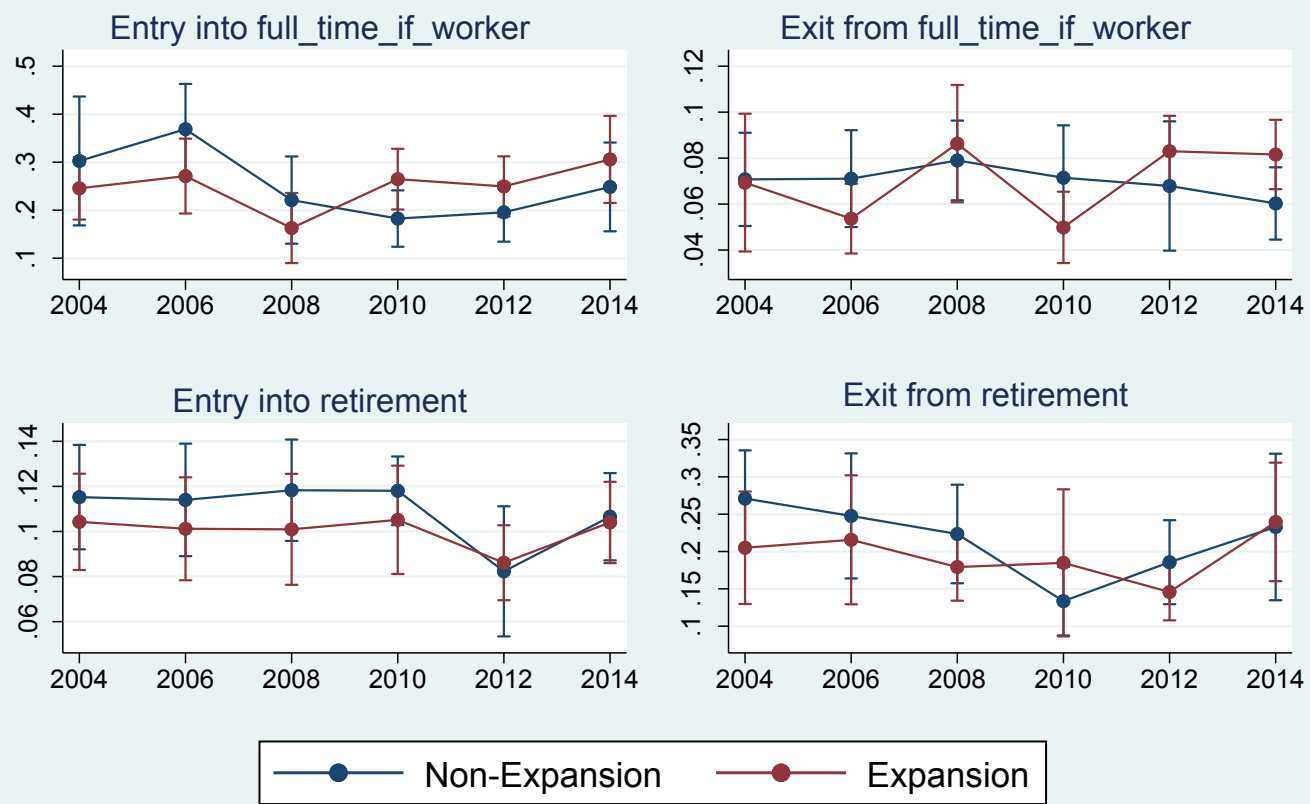

Source: Health and Retirement Study 


\section{Figure 19}

Trends in full-time work and retirement transitions, by state Medicaid expansion status Individuals ages 55-62 at baseline, education_HS_or_less
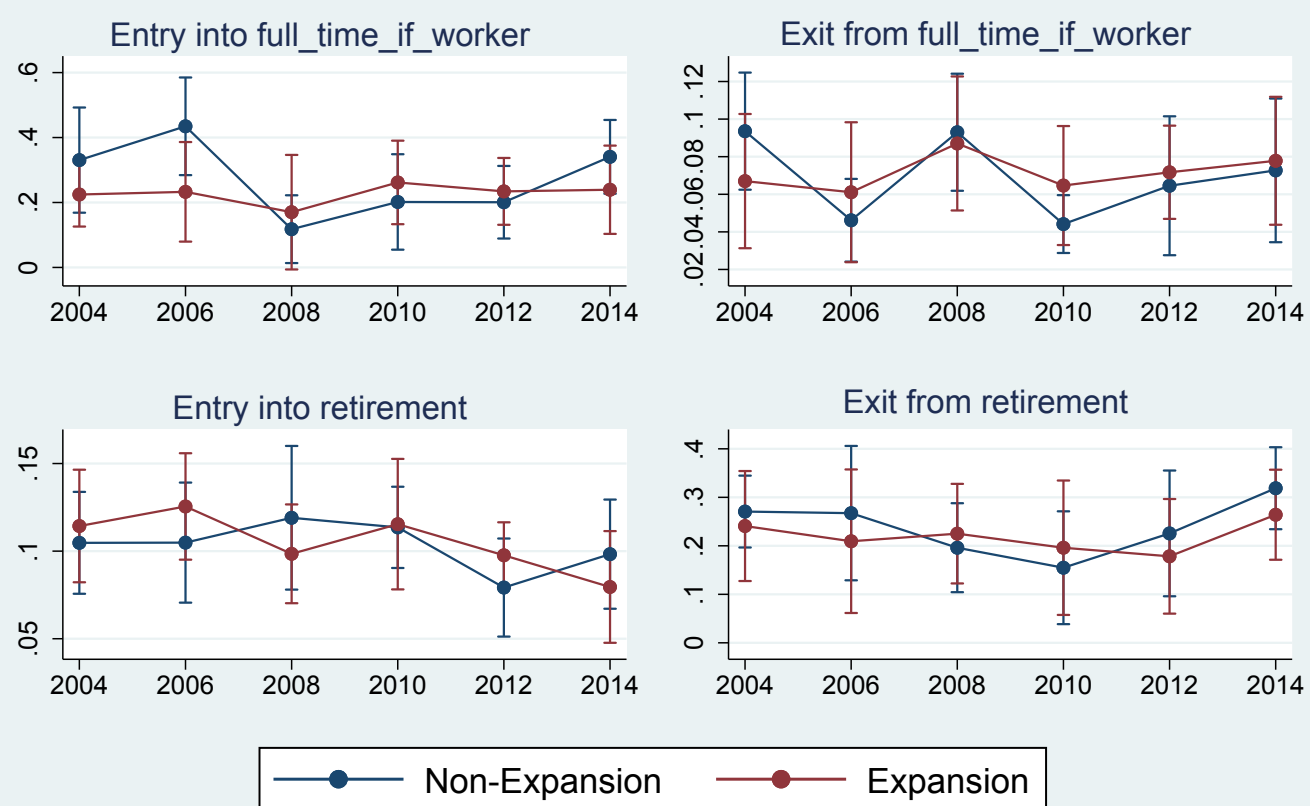

$\longrightarrow$ Expansion

Source: Health and Retirement Study

\section{Figure 20}

Trends in full-time work and retirement transitions, by state Medicaid expansion status Individuals ages 55-62 at baseline, health_fair_or_poor

Entry into full_time_if_worker

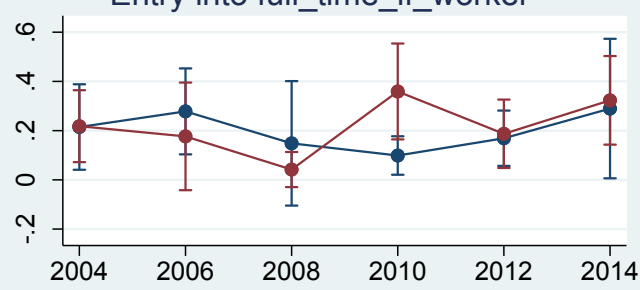

Entry into retirement

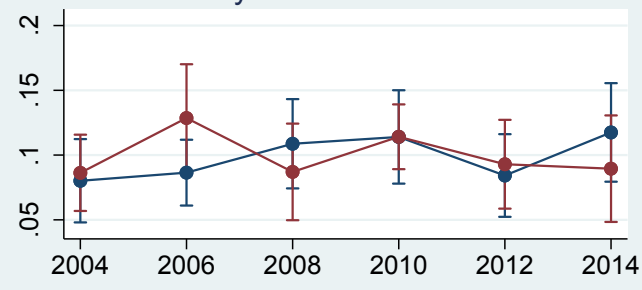

Exit from full_time_if_worker

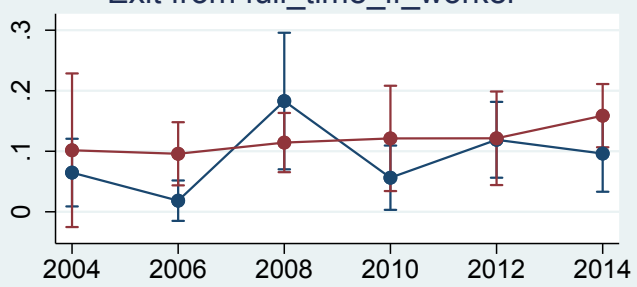

Exit from retirement

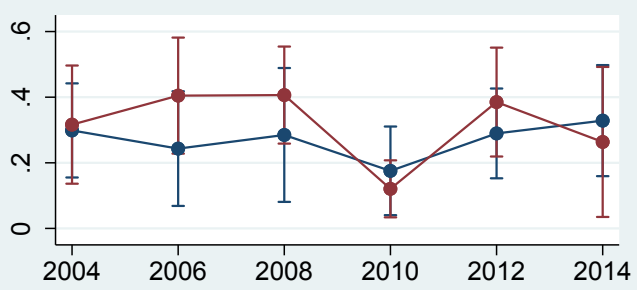

Source: Health and Retirement Study 


\section{Figures 21}

Age profiles of In_the_labor_force before and after 2014

Outcome: All, not regression adjusted

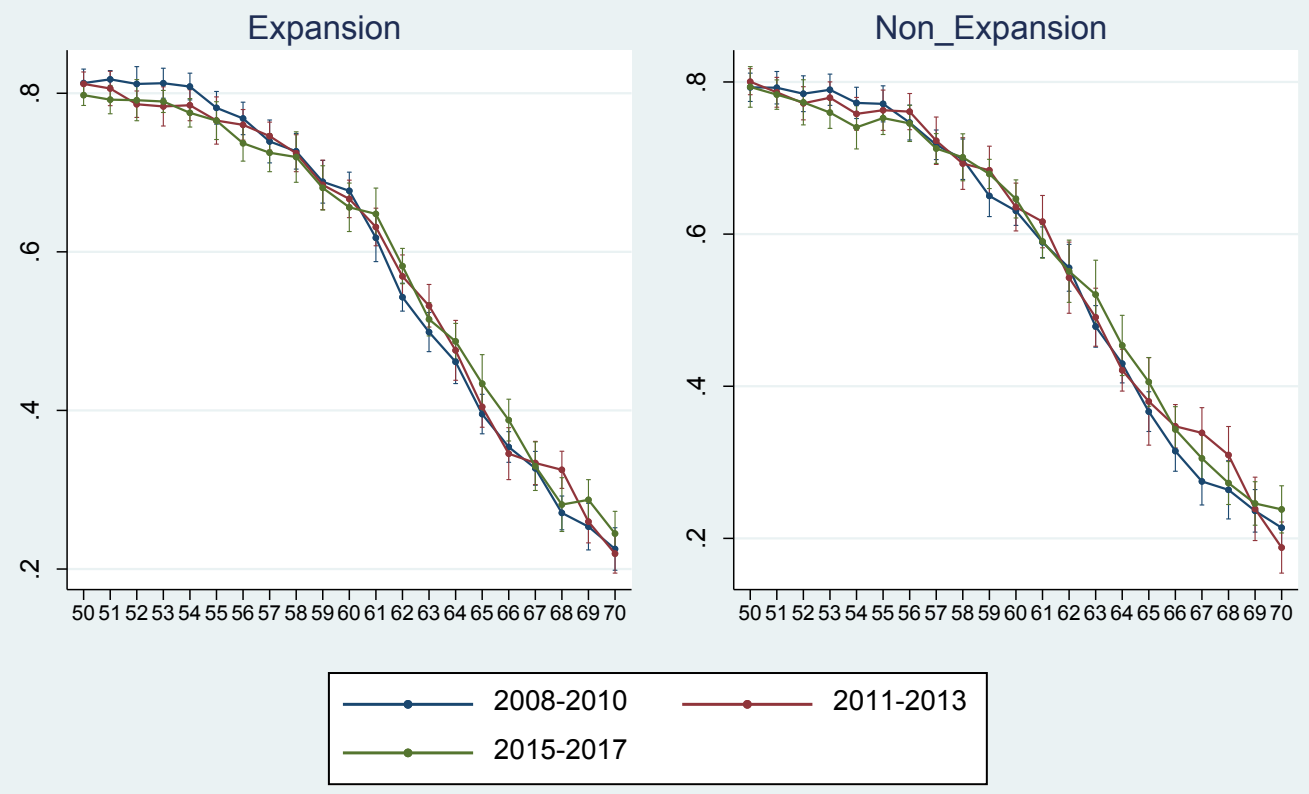

Source: CPS ASEC

\section{Figure 22}

Age profiles of In_the_labor_force before and after 2014 Outcome: Education_HS_or_less, not regression adjusted
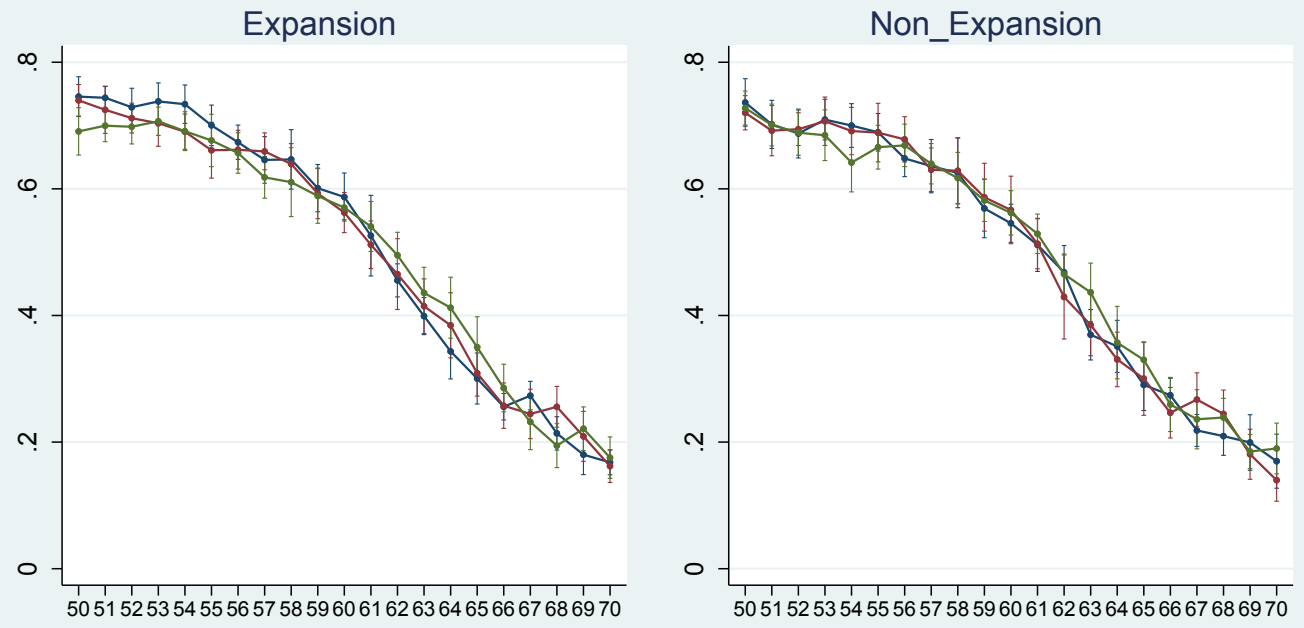


\section{Figure 23}

Age profiles of In_the_labor_force before and after 2014

Outcome: Health_fair_or_poor, not regression adjusted

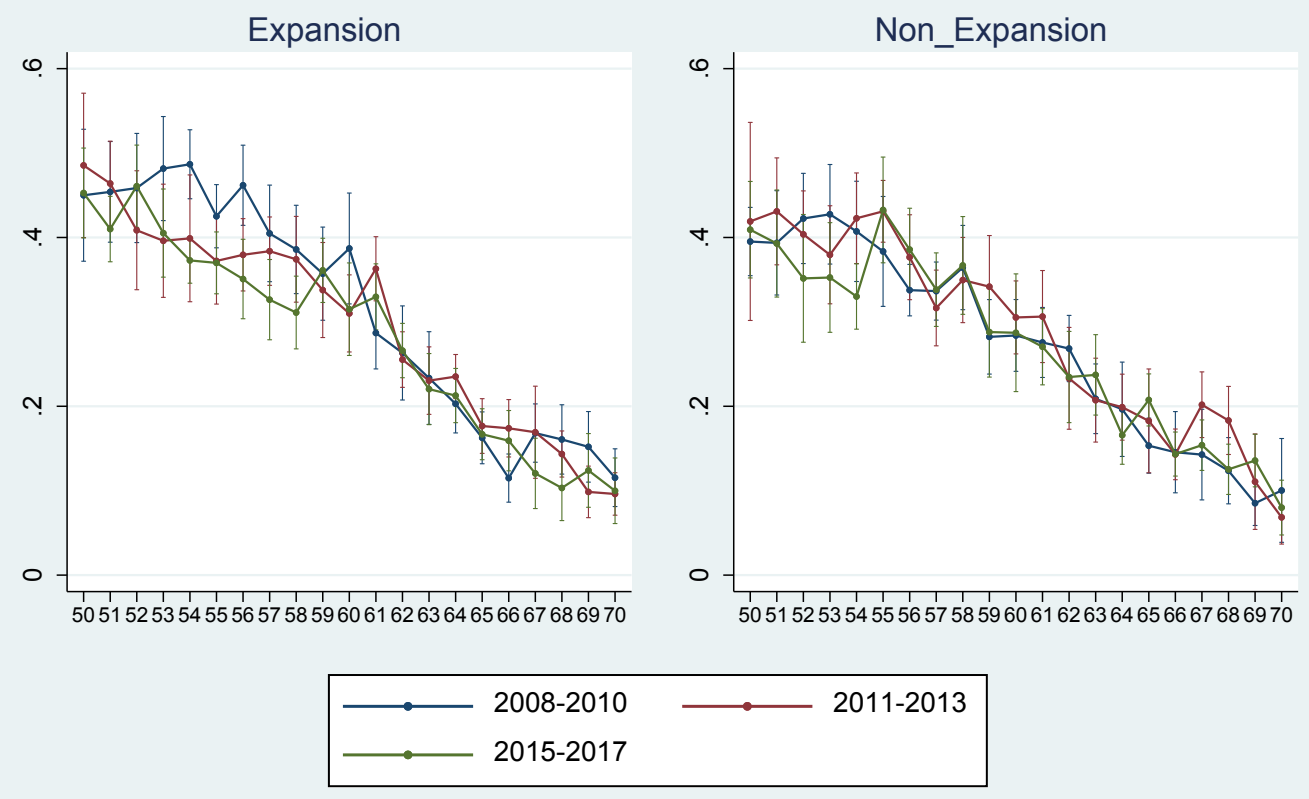

Source: CPS ASEC

\section{Figure 24}

Age profiles of Full_time_if_worker before and after 2014 Outcome: All, not regression adjusted

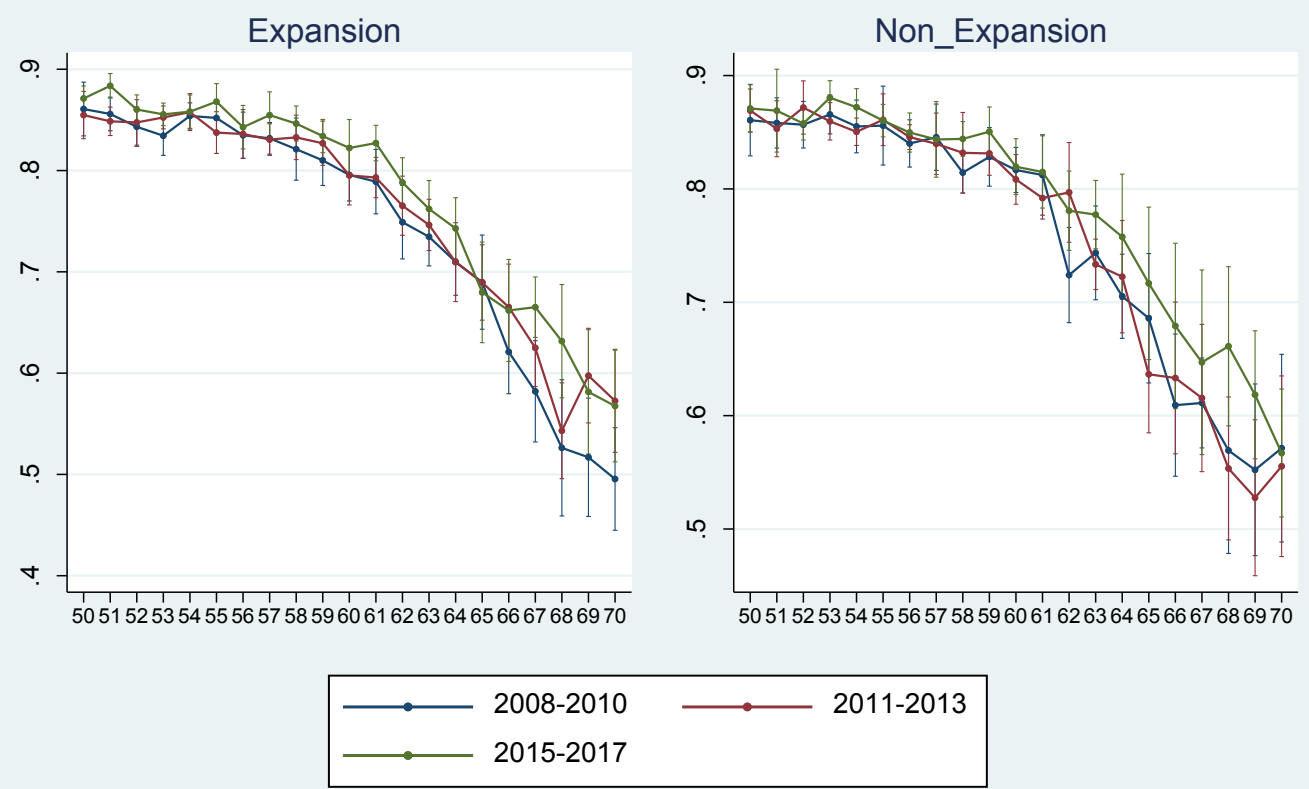

Source: CPS ASEC 


\section{Figure 25}

Age profiles of Full_time_if_worker before and after 2014 Outcome: Education_HS_or_less, not regression adjusted
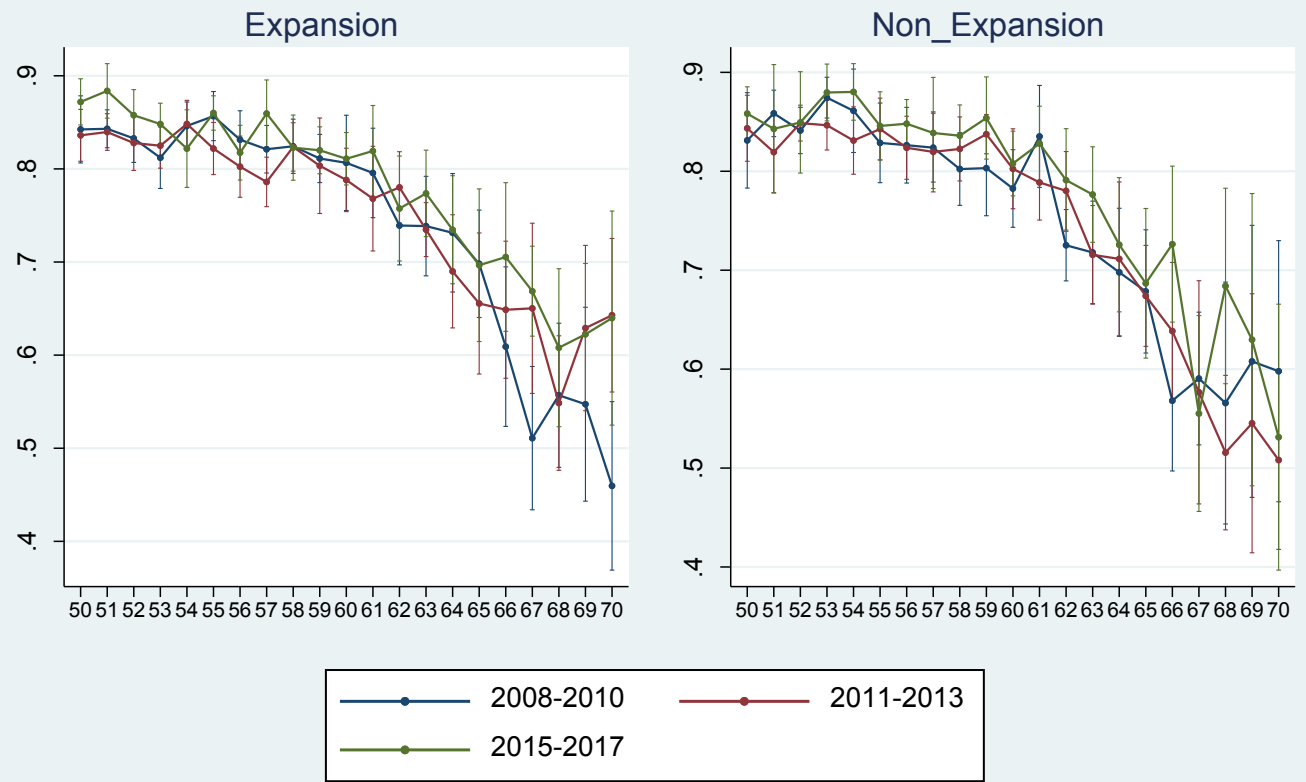

Source: CPS ASEC

\section{Figure 26}

Age profiles of In_the_labor_force before and after 2014

Outcome: Health_fair_or_poor, not regression adjusted

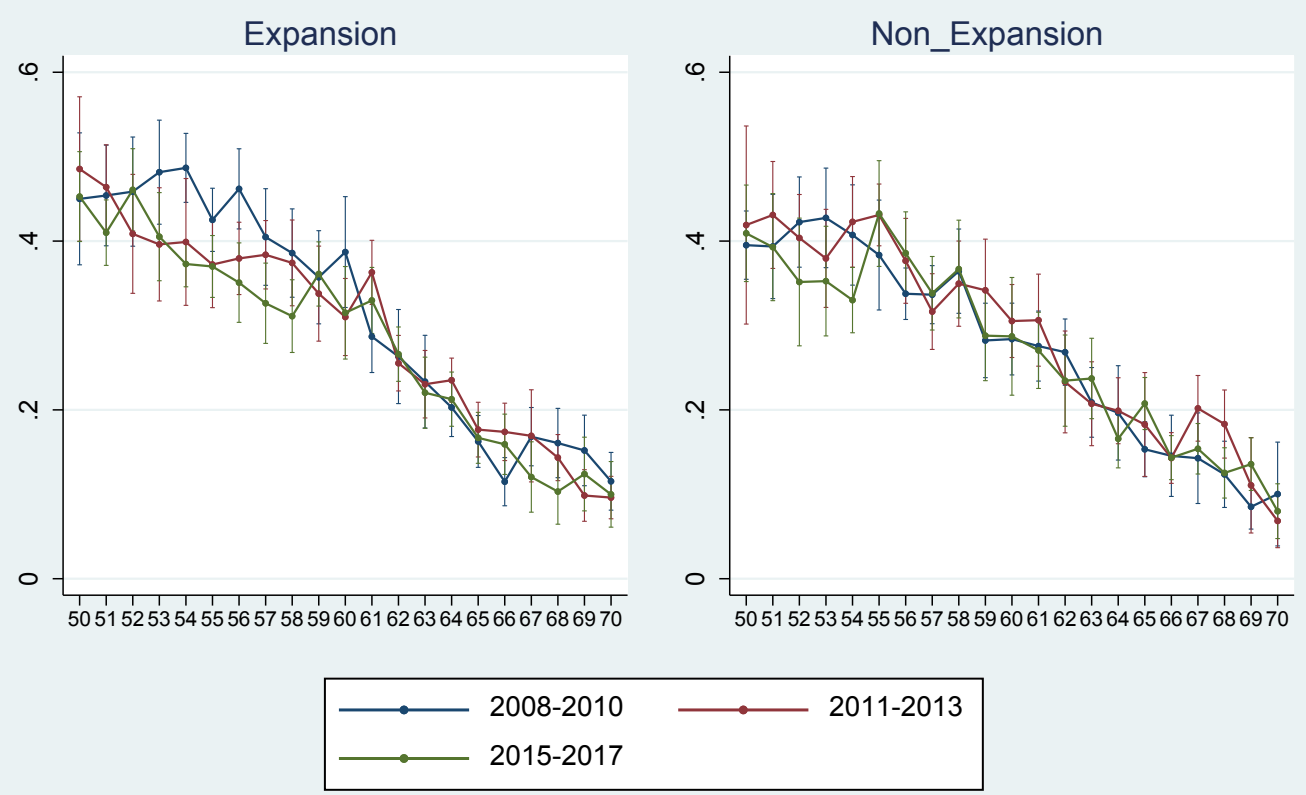

Source: CPS ASEC 


\section{Figure 27}

Age profiles of Receiving_Social_Security before and after 2014

Outcome: All, not regression adjusted
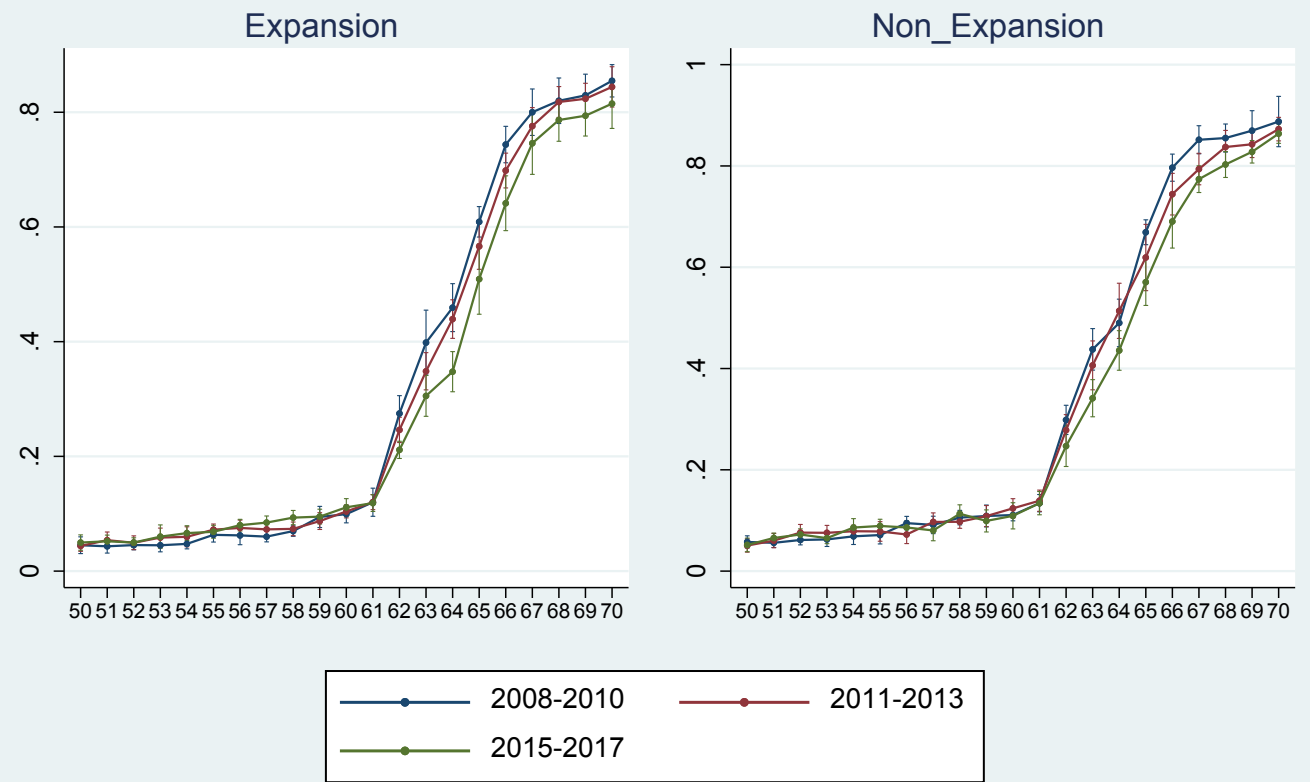

Source: CPS ASEC

\section{Figure 28}

Age profiles of Receiving_Social_Security before and after 2014 Outcome: Education_HS_or_less, not regression adjusted

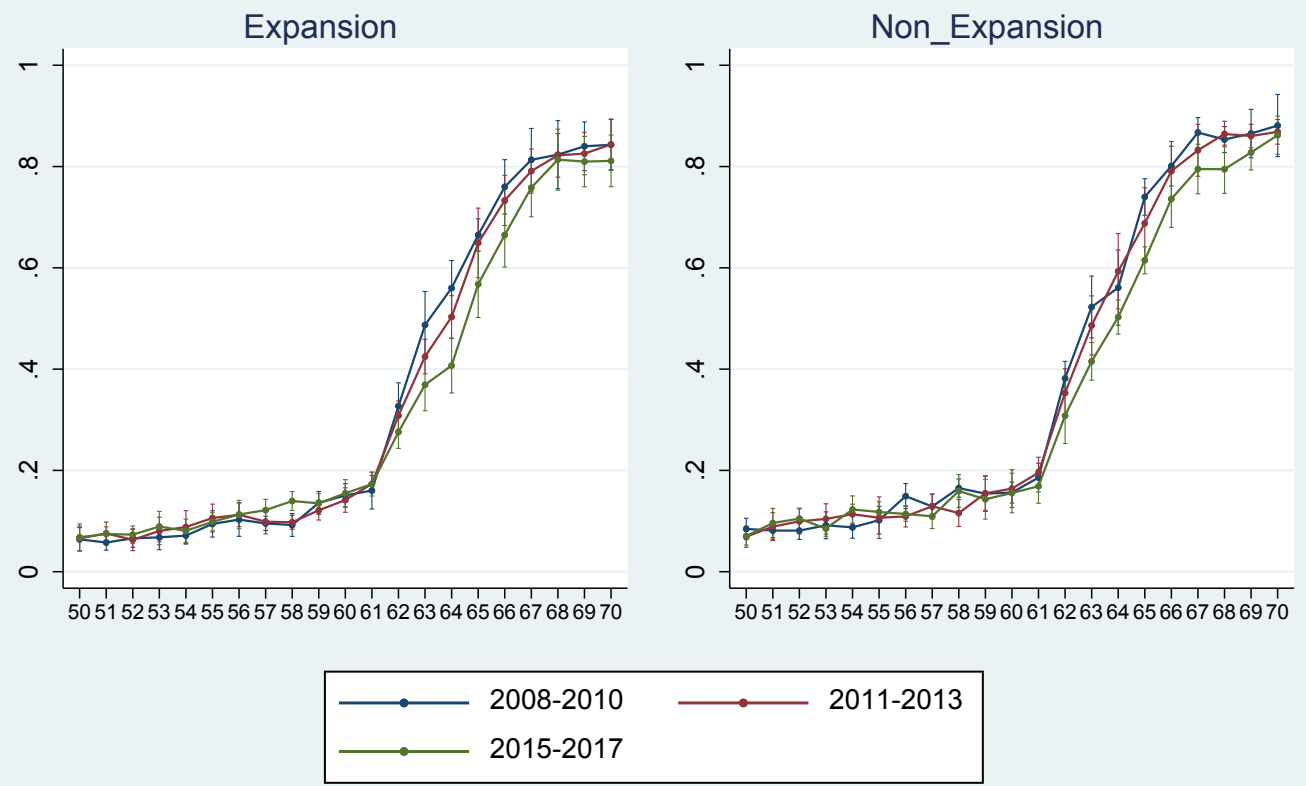

Source: CPS ASEC 


\section{Figure 29}

Age profiles of Receiving_Social_Security before and after 2014 Outcome: Health_fair_or_poor, not regression adjusted

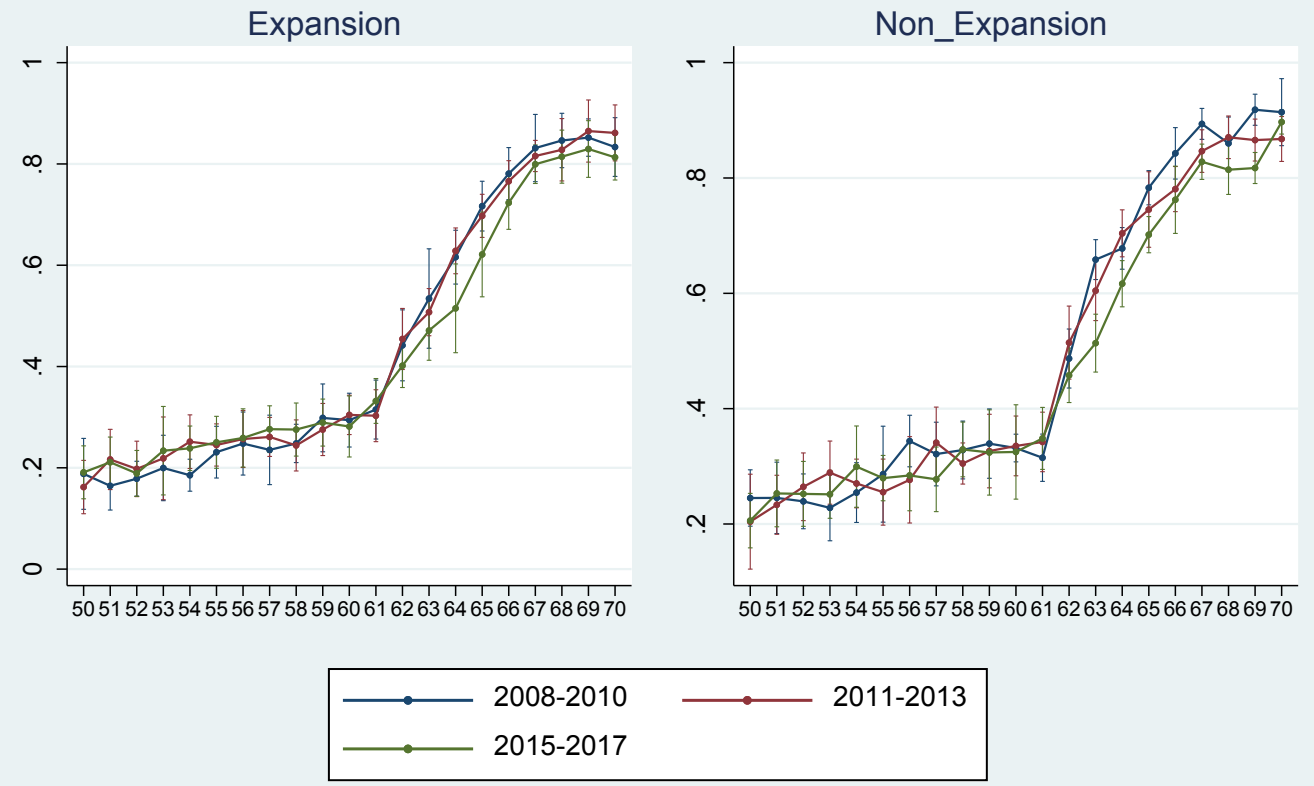

Source: CPS ASEC 